University of Nebraska - Lincoln

DigitalCommons@University of Nebraska - Lincoln

\title{
Enzymology of Electron Transport: Energy Generation With Geochemical Consequences
}

Thomas J. DiChristina

Georgia Institute of Technology, Thomas.Dichristina@biology.gatech.edu

James K. Fredrickson

Pacific Northwest National Laboratory, jim.fredrickson@pnl.gov

John M. Zachara

Pacific Northwest National Laboratory, john.zachara@pnl.gov

Follow this and additional works at: https://digitalcommons.unl.edu/usdoepub

Part of the Bioresource and Agricultural Engineering Commons

DiChristina, Thomas J.; Fredrickson, James K.; and Zachara, John M., "Enzymology of Electron Transport: Energy Generation With Geochemical Consequences" (2005). US Department of Energy Publications. 297. https://digitalcommons.unl.edu/usdoepub/297

This Article is brought to you for free and open access by the U.S. Department of Energy at DigitalCommons@University of Nebraska - Lincoln. It has been accepted for inclusion in US Department of Energy Publications by an authorized administrator of DigitalCommons@University of Nebraska - Lincoln. 


\title{
Enzymology of Electron Transport: Energy Generation With Geochemical Consequences
}

\author{
Thomas J. DiChristina
}

\author{
School of Biology \\ Georgia Institute of Technology \\ Environ Sci Technol Building \\ Atlanta, Georgia, 30332, U.S.A. \\ Thomas.Dichristina@biology.gatech.edu
}

\author{
Jim K. Fredrickson and John M. Zachara \\ Fundamental Sciences Division \\ Pacific Northwest National Laboratory \\ P.O. Box 999, MSIN P7-50 \\ Richland, Washington, 99352, U.S.A. \\ Jim.Fredrickson@pnl.gov_John.Zachara@pnl.gov
}

\section{INTRODUCTION}

Dissimilatory metal-reducing bacteria (DMRB) are important components of the microbial community residing in redox-stratified freshwater and marine environments. DMRB occupy a central position in the biogeochemical cycles of metals, metalloids and radionuclides, and serve as catalysts for a variety of other environmentally important processes including biomineralization, biocorrosion, bioremediation and mediators of ground water quality. DMRB are presented, however, with a unique physiological challenge: they are required to respire anaerobically on terminal electron acceptors which are either highly insoluble (e.g., $\mathrm{Fe}(\mathrm{III})$ - and $\mathrm{Mn}(\mathrm{IV})$-oxides) and reduced to soluble end-products or highly soluble (e.g., U(VI) and $\mathrm{Tc}(\mathrm{VII})$ ) and reduced to insoluble end-products. To overcome physiological problems associated with metal and radionuclide solubility, DMRB are postulated to employ a variety of novel respiratory strategies not found in other gram-negative bacteria which respire on soluble electron acceptors such as $\mathrm{O}_{2}, \mathrm{NO}_{3}{ }^{-}, \mathrm{SO}_{4}{ }^{2-}$, and $\mathrm{CO}_{2}$. The novel respiratory strategies include 1) direct enzymatic reduction at the outer membrane, 2) electron shuttling pathways and 3) metal solubilization by exogenous or bacterially-produced organic ligands followed by reduction of soluble organic-metal compounds. The first section of this chapter highlights the latest findings on the enzymatic mechanisms of metal and radionuclide reduction by two of the most extensively studied DMRB (Geobacter and Shewanella), with particular emphasis on electron transport chain enzymology. These advances have drawn significantly upon genomic data for isolated microorganisms from the genera Geobacter and Shewanella (see chapter by Nelson and Methé 2005). The second section emphasizes the geochemical consequences of DMRB activity, including the direct and indirect effects on metal solubility, the reductive transformation of Fe- and Mn-containing minerals, and the biogeochemical cycling of metals at redox interfaces in chemically stratified environments.

\section{ENZYMATIC BASIS OF IRON AND MANGANESE REDUCTION}

The electron transport systems of gram-negative bacteria are generally described as inner membrane (IM)-associated electron and proton carriers that 1) mediate electron transfer from 
primary donor to terminal electron acceptor and 2) conserve energy released during electron transfer to the generation of ATP (Madigan and Martinko 2006). Figure 1 displays the electron transport chain enzymology of Escherichia coli respiring high concentrations of dissolved $\mathrm{O}_{2}$ as electron acceptor. The $E$. coli electron transport system is modular in design with a membrane-soluble quinone pool $(\mathrm{Q})$ linking dehydrogenase complexes at the head end with terminal reductase complexes at the terminus. Dehydrogenase complexes include electron donor-specific oxido-reductases (e.g., NADH dehydrogenase) that couple oxidation of specific electron donors to reduction of a series of membrane-associated electron carriers arranged in order of increasingly more positive electric potential $\left(E_{0}{ }^{\prime}\right)$. These electron carriers include flavoproteins $(\mathrm{Fp})$ and $\mathrm{FeS}$ proteins that translocate protons across the IM to the periplasm and direct electrons to the $\mathrm{Q}$ pool, respectively. Reduced $\mathrm{Q}$ is subsequently protonated to $\mathrm{QH}_{2}$ at the inner aspect of the IM. $\mathrm{QH}_{2}$ carries protons across the IM to the periplasm and transfers electrons to cytochrome $b_{556}$ and $b_{562}$, two components of the terminal reductase complex that transfer electrons to cytochrome $o$ (topologically located at the inner aspect of the IM) and ultimately to $\mathrm{O}_{2}$. Cytochrome $o$ catalyzes both the translocation of a proton across the IM to the periplasm and the terminal reduction of $\mathrm{O}_{2}$ to $\mathrm{H}_{2} \mathrm{O}$. A proton motive force (PMF) is generated by 1) proton translocation across the IM by dehydrogenase complexes, $\mathrm{QH}_{2}$ and cytochrome $o$, and 2) proton consumption during the terminal reduction of $\mathrm{O}_{2}$ to $\mathrm{H}_{2} \mathrm{O}$ by cytochrome $o$. PMF generated in this manner drives ATP synthesis as protons are translocated back into the cytoplasm through an IM-localized ATPase, catalyzing the phosporylation of ADP to ATP (Madigan and Martinko 2006).

$\mathrm{Fe}(\mathrm{III})$ - and Mn(IV)-respiring DMRB, on the other hand, are presented with a unique physiological problem: they are required to respire anaerobically on terminal electron acceptors found largely in crystalline form or as amorphous (oxy)hydroxide particles presumably unable to contact IM-localized electron transport systems. A DMRB culture actively respiring solid $\mathrm{Mn}(\mathrm{IV})$ oxides as anaerobic electron acceptor is displayed in Figure 2. To overcome the problem of respiring solid electron acceptors, Fe(III)- and $\mathrm{Mn}$ (IV)-respiring DMRB are postulated to employ a variety of novel respiratory strategies not found in other gram-negative bacteria that respire on soluble electron acceptors such as $\mathrm{O}_{2}, \mathrm{NO}_{3}{ }^{-}, \mathrm{SO}_{4}{ }^{2-}$ and $\mathrm{CO}_{2}$ including 1) direct enzymatic reduction of solid $\mathrm{Fe}(\mathrm{III})$ and $\mathrm{Mn}(\mathrm{IV})$ oxides via outer membrane (OM)-localized metal reductases (Myers and Myers 1992, 2003a; Beliaev and Saffarini 1998; DiChristina et al. 2002) 2) a two-step, electron shuttling pathway in which exogenous electron shuttling compounds (e.g., humic acids, melanin, phenazines, antibiotics, AQDS) are first enzymatically reduced and subsequently chemically oxidized by the solid $\mathrm{Fe}(\mathrm{III})$ and $\mathrm{Mn}(\mathrm{IV})$ oxides in a second (abiotic) electron transfer reaction (Lovley et al. 1996;

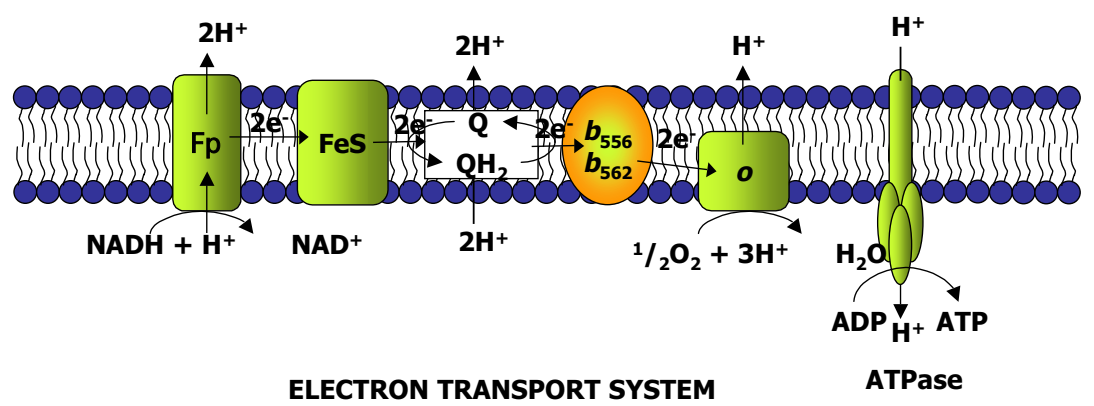

Figure 1. Electron transport and proton translocation processes of the E. coli aerobic respiratory chain at high $\mathrm{O}_{2}$ concentrations with $\mathrm{NADH}_{2}$ as electron donor. Fp, flavoprotein; FeS, iron-sulfur protein; Q, quinone pool; $b_{556}$ and $b_{562}, b$-type cytochromes; $o$, cytochrome $o$. 


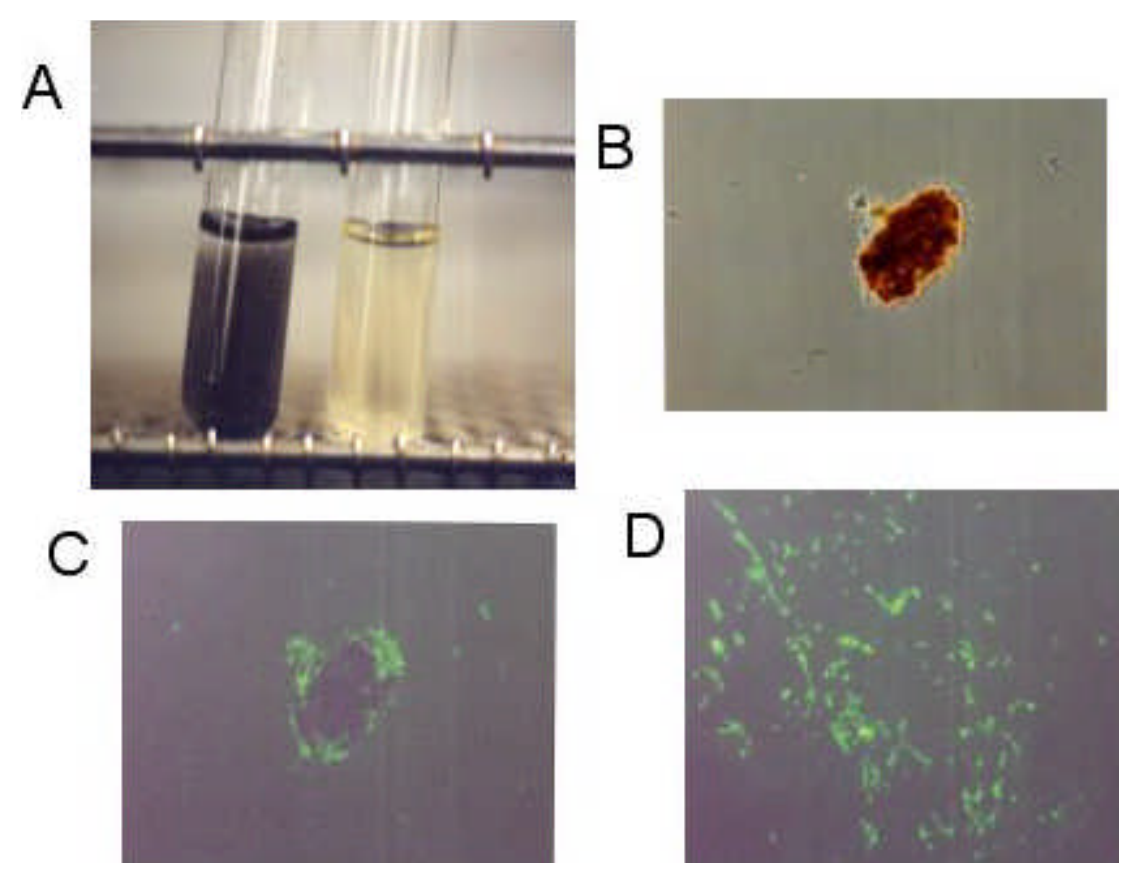

Figure 2. DMRB Shewanella putrefaciens strain 200 actively respiring solid Mn(IV) oxides as anaerobic electron acceptor. (A) Anaerobic cell suspensions at the beginning (tube on left side) and end (tube on right side) of a 24-hour anaerobic incubation period (note color change indicative of reductive dissolution of black Mn(IV) particles to clear, soluble reduced Mn), (B) phase contrast micrograph of cells coating the surface of a Mn(IV) oxide particle at the beginning of the anaerobic growth period, (C) epifluorescence micrograph of same field of view as in (B) with acridine orange-stained cells, (D) epifluorescence micrograph of acridine orange-stained cells at the end of the 24-hour anaerobic incubation period (note the absence of the solid Mn(IV) particles).

Coates et al. 1998, 2002; Newman and Kolter 2000; Turick et al. 2002; Hernandez et al. 2004; DiChristina et al. 2005) 3) an analogous two-step reduction pathway involving endogenous, electron shuttling compounds (Newman and Kolter 2000; Saffarini et al. 2002) and 4) a twostep, Fe(III) solubilization-reduction pathway in which solid Fe(III) oxides are first dissolved by exogenous or bacterially-produced organic complexing ligands, followed by uptake and reduction of the soluble organic Fe(III) forms by periplasmic Fe(III) reductases (Arnold et al. 1988; Lovley and Woodward 1996; Pitts et al. 2003). Although the number of DMRB species continues to increase rapidly and has now reached nearly 100 (Lovley et al. 2004), the enzymatic basis of electron transfer to metals has been most extensively studied in metalrespiring members of the genera Geobacter and Shewanella. The following section highlights the latest findings on the enzymatic basis of Fe(III) and $\mathrm{Mn}(\mathrm{IV})$ reduction by Geobacter and Shewanella, with particular emphasis on electron transport chain enzymology.

\section{Direct enzymatic reduction at the outer membrane}

Shewanella and Geobacter catalyze the direct enzymatic reduction of solid Fe(III) and $\mathrm{Mn}(\mathrm{III}, \mathrm{IV})$ oxides via an electron transport chain arranged in a canonical, highly branched fashion. Hydrogenase and flavin-containing dehydrogenase complexes of both Shewanella and Geobacter (Myers and Myers 1993a; Lloyd et al. 2000) oxidize a variety of electron donors (e.g., $\left.\mathrm{H}_{2}, \mathrm{NAD}(\mathrm{P}) \mathrm{H}\right)$ and transfer electrons to a menaquinone pool (Myers and Nealson 1990; Myers and Myers 1993b; Nevin and Lovley 2002; Saffarini et al. 2002). In S. oneidensis, 
menaquinol diffuses within the IM to the quinol oxidation site of CymA, a $21 \mathrm{kDa}$ tetraheme cytochrome $c$ that oxidizes menaquinol and is thought to transfer electrons to MtrA, a $32 \mathrm{kDa}$ decaheme cytochrome $c$ located in the periplasm (Myers and Myers 2000; Schwalb et al. 2003). In G. sulfurreducens, $\mathrm{PpcB}$ (a $36 \mathrm{kDa}$ diheme cytochrome $c$ ) essentially carries out the same function as CymA (although CymA and $\mathrm{PpcB}$ display little or no amino acid sequence homology), oxidizing the menaquinol pool and transferring electrons to PpcA, a $10 \mathrm{kDa}$ triheme cytochrome $c$ located in the G. sulfurreducens periplasm (Lloyd 2003). As with PpcB, G. sulfurreducens PpcA does not display significant sequence similarity to any $S$. oneidensis $c$-type cytochromes, suggesting that they have a different evolutionary origin (Lloyd 2003). Electrons from the $S$. oneidensis menaquinol pool are transferred to one of four electronaccepting, c-type hemes within CymA, followed by inter-heme electron transfer (according to decreasing heme redox potential) until a final transfer is made to subsequent electron carriers in the periplasmic space (Harada et al. 2002). cymA-deficient mutants of S. oneidensis are unable to reduce $\mathrm{NO}_{3}{ }^{-}, \mathrm{Fe}(\mathrm{III}), \mathrm{Mn}(\mathrm{IV})$ or fumarate as electron acceptor (Myers and Myers 1997), an indication that CymA is a central branchpoint of the $S$. oneidensis electron transport system. $p p c B$-deficient mutants of G. sulfurreducens, on the other hand, are unable to reduce Fe(III), but retain the ability to reduce fumarate (Butler 2003). The principles of, and rationale for genetic manipulation (including generation of metal respiration-deficient mutants) is discussed in the chapter by Newman and Gralnick (2005).

Electron transport from MtrA in S. oneidensis and PpcA in G. sulfurreducens to solid $\mathrm{Fe}$ (III) oxides is postulated to proceed via an electron transport chain that spans the periplasmic space and terminates on the outside face of the OM (Myers and Myers 1993a; Leang et al. 2003). Electron transfer to solid Fe(III) and Mn(IV) in G. sulfurreducens proceeds via OmcB, an $87 \mathrm{kDa}, 12$-heme cytochrome $c$ tentatively assigned to the inner aspect of the OM (Leang et al. 2003). Correspondingly, Fe(III)-grown G. sulfurreducens cells display higher levels of omcB transcripts (Chin et al. 2004; Methé et al. 2005). All G. sulfurreducens OM cytochromes, however, are not necessarily involved in electron transport to $\mathrm{Fe}(\mathrm{III})$ since $\mathrm{OmcC}$, an $\mathrm{OM}$ cytochrome displaying $73 \%$ identity to $\mathrm{OmcB}$, is not required for $\mathrm{Fe}$ (III) reduction (Leang et al. 2003; Leang and Lovley 2005) and correspondingly, Fe(III)-grown G. sulfurreducens cells do not display higher levels of omcC transcripts (Chin et al. 2004). The terminal electron transfer step to solid $\mathrm{Fe}$ (III) and $\mathrm{Mn}$ (IV) oxides in G. sulfurreducens is postulated to be catalyzed by either OmcD or OmcE, two $c$-type cytochromes that may be exposed on the cell surface (Methé et al. 2005). Results of DNA microarray analysis (as described in the chapter by Nelson and Methé 2005) will identify electron transport chain components with elevated transcript levels during growth on specific electron acceptors.

Similar to Geobacter, the Shewanella OM proteins involved in terminal steps of electron transfer to solid Fe(III) and Mn(IV) oxides have not been definitively identified, yet most likely include several $c$-type cytochromes (Myers and Myers 1992, 2003a). Fe(III) reduction activity is detected in wild-type Shewanella OM fractions (Myers and Myers 1993a), an activity that is severely impaired in Shewanella mutants lacking OM proteins, including several multi-heme $c$-type cytochromes. The $S$. oneidensis genome encodes 42 predicted $c$-type cytochromes (Heidelberg et al. 2002), including those in the $m t r D E F$-omcA-mtrCAB gene cluster. MtrA and MtrD are decaheme $c$-type cytochromes that display 99\% similarity (Pitts et al. 2003), suggesting they may provide complementary function. MtrD is OM-associated, but may be oriented toward the periplasm (Pitts et al. 2003) and therefore not in position to contact solid Fe(III) directly. MtrB is a putative beta-barrel protein postulated to be involved in $\mathrm{OM}$ localization of the $c$-type cytochromes OmcA and MtrC that are involved in electron transfer to Fe(III) and Mn(IV) (Beliaev and Saffarini 1998; Myers and Myers 2002). mtrB mutants display a complete inability to reduce $\mathrm{Mn}(\mathrm{IV})$ and are severely, but not completely, impaired in $\mathrm{Fe}$ (III) reduction activity, yet retain the ability to reduce all other electron acceptors (Beliaev 
and Saffarini 1998). MtrC is an OM-localized decaheme, $c$-type cytochrome required for both $\mathrm{Fe}(\mathrm{III})$ and $\mathrm{Mn}(\mathrm{IV})$ reduction activity. OmcA, on the other hand, is an OM decaheme $c$-type cytochrome involved in electron transport to $\mathrm{Mn}(\mathrm{IV})$ and not $\mathrm{Fe}(\mathrm{III})$ (Myers and Myers 2001). omcA-deficient mutants reduce Mn(IV) at $45 \%$ wild-type rates. Interestingly, $m$ trC overexpression in an $o m c A$-deficient mutant restores $\mathrm{Mn}(\mathrm{IV})$ reduction activity to greater than wild-type rates, an indication that the functional roles of MtrC and OmcA at least partially overlap in the electron transport pathway to Mn(IV) (Myers and Myers 2003b). The functions of $\mathrm{MtrC}$ and $\mathrm{OmcA}$ in $\mathrm{Fe}$ (III) reduction remain unclear, yet they are postulated to be major components of the $\mathrm{Fe}(\mathrm{III})$ terminal reductase.

Some of the most convincing genetic evidence supporting the hypothesis that Shewanella localizes $\mathrm{Fe}(\mathrm{III})$ and $\mathrm{Mn}(\mathrm{IV})$ reductases to the $\mathrm{OM}$ has been derived from genetic studies with S. putrefaciens (DiChristina and DeLong 1994; DiChristina et al. 2002). Genetic mutant complementation analyses (as outlined in chapter by Newman and Gralnick 2005) indicated that a $23.3 \mathrm{~kb} \mathrm{~S}$. putrefaciens wild-type DNA fragment conferred Fe(III) reduction activity to a set of $10 \mathrm{Fe}$ (III) reduction-deficient mutants of $S$. putrefaciens. The smallest complementing DNA fragment contained one open reading frame (ORF) whose translated product displayed $87 \%$ sequence similarity to Aeromonas hydrophila ExeE, a member of the GspE family of proteins found in Type II protein secretion systems. GspE insertional mutants (constructed by targeted replacement of wild-type $g s p E$ with an insertionally inactivated $g s p E$ construct) are unable to respire anaerobically on solid $\mathrm{Fe}(\mathrm{III})$ or $\mathrm{Mn}(\mathrm{IV})$ oxides, yet retain the ability to respire all other electron acceptors including soluble complexes of Fe(III) and Mn(III) (Kostka et al. 1995; Pitts et al. 2003). Nucleotide sequence analysis of regions flanking $g s p E$ revealed one partial and two complete ORFs whose translated products displayed 55-70\% sequence similarity to the GspD-G homologs of other Type II protein secretion systems. A heme-containing protein complex displaying $\mathrm{Fe}(\mathrm{III})$ reductase activity is present in the peripheral proteins loosely attached to the outside face of the wild-type OM, yet is missing from this location in the $g s p E$ mutants. Membrane fractionation studies with the wild-type strain support this finding: the heme-containing Fe(III) reductase complex is detected in the $\mathrm{OM}$ but not the IM or cytoplasmic fractions. These findings provide the first genetic evidence linking anaerobic $\mathrm{Fe}(\mathrm{III})$ and $\mathrm{Mn}(\mathrm{IV})$ respiration to Type II protein secretion and provide additional biochemical evidence supporting OM localization of Shewanella Fe(III) and Mn(IV) reductases (DiChristina and DeLong 1994; DiChristina et al. 2002).

Gram-negative bacteria secrete soluble exoproteins to the cell periphery or exterior via five known protein secretion systems (Desvaux et al. 2004). Type II protein secretion is part of the main terminal branch of the general secretory (GSP) pathway (Pugsley 1993; Pugsley et al. 1997; Filloux 2004) and is generally comprised of 12-to-16 proteins encoded by a contiguous cluster of moderately-to-highly conserved pul (or $g s p$ ) genes, usually in the same order. Pullulanase secretion by the plant cell wall-degrading microorganism Klebsiella oxytoca is one of the best characterized Type II protein secretion systems and a working model for pullulanase secretion has been proposed (Pugsley et al. 1997). Nascent pullulanase is first directed into and across the cytoplasmic membrane where it folds and is transiently anchored to the periplasmic aspect of the cytoplasmic membrane. After processing (signal peptide cleavage, disulfide bond formation, fatty acylation), the mature pullulanase is guided across the periplasmic space by the Type II secretion pseudopilus (GspG, H, I, J complex) and interacts with the OMassociated, multimeric GspD channel. Pullulanase is subsequently attached to the outside face of the outer membrane via a fatty acid tail. The ferE homolog, gspE, is postulated to encode a secretion ATPase that drives the secretion process, including the rapid polymerization and depolymerization reactions associated with pseudopilus extension and retraction (Filloux 2004). Peripherally attached pullulanase cleaves alpha-1,6 linkages in branched maltodextrin polymers such as glycogen or amylopectin of plant cell wall material, thereby releasing linear 
dextrins for bacterial cell uptake and metabolism. Based on the $K$. oxytoca Type II pullulanase secretion model and the previously reported involvement of $S$. putrefaciens outer membrane proteins in dissimilatory $\mathrm{Fe}(\mathrm{III})$ and $\mathrm{Mn}(\mathrm{IV})$ reduction, it has been postulated that the $\mathrm{Fe}(\mathrm{III})$ and $\mathrm{Mn}(\mathrm{IV})$ respiratory deficiencies of Type II protein secretion mutants are due to their inability to secrete $\mathrm{Fe}(\mathrm{III})$ and $\mathrm{Mn}(\mathrm{IV})$ terminal reductases to the outside face of the $S$. putrefaciens outer membrane (DiChristina et al. 2002). A working model of the direct enzymatic pathway for reduction of solid Fe(III) oxides in Shewanella is displayed in Figure 3.

\section{Electron shuttling pathways}

A variety of Fe(III)-respiring DMRB, including Shewanella and Geobacter, can employ redox-active compounds (e.g., humic acids, melanin, phenazines, antibiotics, AQDS) as exogenous electron shuttles to reduce extracellular Fe(III) oxides (Lovley et al. 1996). The $\mathrm{Fe}(\mathrm{III})$ and $\mathrm{Mn}(\mathrm{IV})$ reduction-deficiencies of Shewanella Type II protein secretion mutants are rescued by addition of AQDS (DiChristina et al. 2005). S. oneidensis gspD insertional mutants are unable to respire anaerobically on solid Fe(III) or Mn(IV), yet retain the ability to respire all other electron acceptors, including AQDS. The ability to respire $50 \mathrm{mM}$ solid Fe(III) or $\mathrm{Mn}(\mathrm{IV})$ is rescued in the $S$. oneidensis $g s p D$ insertional mutants by addition of $50 \mu \mathrm{M}$ AQDS, an indication that the AQDS electron shuttling pathway is able to overcome the defect in the Type II protein secretion-linked pathway for respiration on solid Fe(III) and Mn(IV). AQDS is toxic to Shewanella cells above a critical threshold concentration and the efflux pump protein TolC protects Shewanella cells from AQDS toxicity by mediating AQDS efflux (Shyu et al. 2002). Electron transfer to AQDS also requires the OM protein MtrB, although its role in AQDS reduction remains unknown (Shyu et al. 2002).

Solid Fe(III) reduction by Shewanella is also stimulated by redox-active antibiotics and phenazines (Hernandez et al. 2004). Phenazines are similar in structure to AQDS and function as electron shuttles between Shewanella cells and solid Fe(III) oxides. Redox-active antibiotics (e.g., bleomycin) also function as shuttles for extracellular electron transfer to solid electron acceptors. Bacterially-produced phenazines (e.g., synthesized by Pseudomonas chlororaphis PCL1391) stimulate Fe(III) reduction by bacteria unable to produce them (e.g., S. oneidensis MR-1) (Hernandez et al. 2004). In addition, melanin (a humic acid-like compound synthesized by $S$. algae $\mathrm{BrY}$ in the presence of high concentrations of tyrosine) will enhance rates of Fe(III) oxide reduction (Turick et al. 2002). Melanin may have a dual function by acting as both an electron shuttle and an $\mathrm{Fe}$ (II)-complexing agent that prevents $\mathrm{Fe}$ (II) from adsorbing to and blocking $\mathrm{Fe}$ (III) oxide surface sites. A working model of the exogenous electron shuttling pathway for AQDS-mediated reduction of solid Fe(III) oxides by Shewanella is displayed in Figure 4.

Shewanella (and Geothrix fermentans) may also synthesize and release endogenous compounds that shuttle electrons to solid Fe(III) oxides (Newman and Kolter 2000; Nevin and Lovley 2002). Fe(III)-reducing G. metallireducens, on the other hand, does not appear to produce endogenous electron shuttles (Nevin and Lovley 2000). S. algae BrY produces melanin as a soluble electron shuttle for reduction of solid Fe(III) oxides (Turick et al. 2002). $S$. algae-produced melanin oxidizes $c$-type cytochromes at the cell surface and reduces solid Fe(III) oxides extracellularly (Turick et al. 2002). S. oneidensis MR-1 mutants defective in $m e n C$ (encoding $o$-succinylbenzoic acid synthase) are deficient in menaquinone production and are unable to reduce AQDS, fumarate, thiosulfate, sulfite, DMSO or solid Fe(III) and Mn(IV) (Newman and Kolter 2000). Menaquinone is detected in the spent media of the wild-type strain, but not the menC mutants. Spent medium from the wild-type strain restores $\mathrm{Fe}$ (III) reduction activity to the men $C$ mutant, while spent media from menC mutant does not. $S$. oneidensis MR-1 mutants defective in either menD or menB (encoding components of the menaquinone biosynthetic pathway) are also unable to reduce solid Fe(III) oxides (Saffarini et al. 2002). Vitamin $\mathrm{K}_{2}$ (a menaquinone analog) restores the ability of the menD or menB 


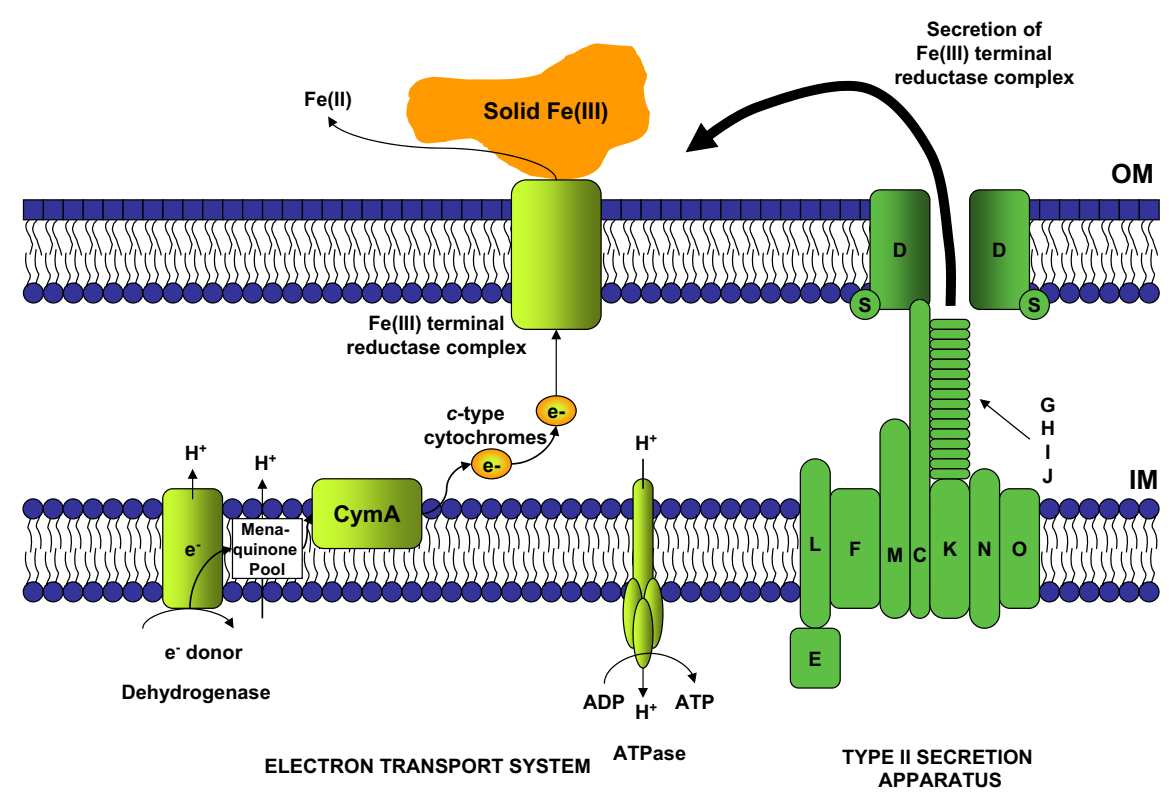

Figure 3. Working model for type II protein secretion-linked, direct enzymatic reduction of solid $\mathrm{Fe}$ (III)-oxides at the outer membrane.

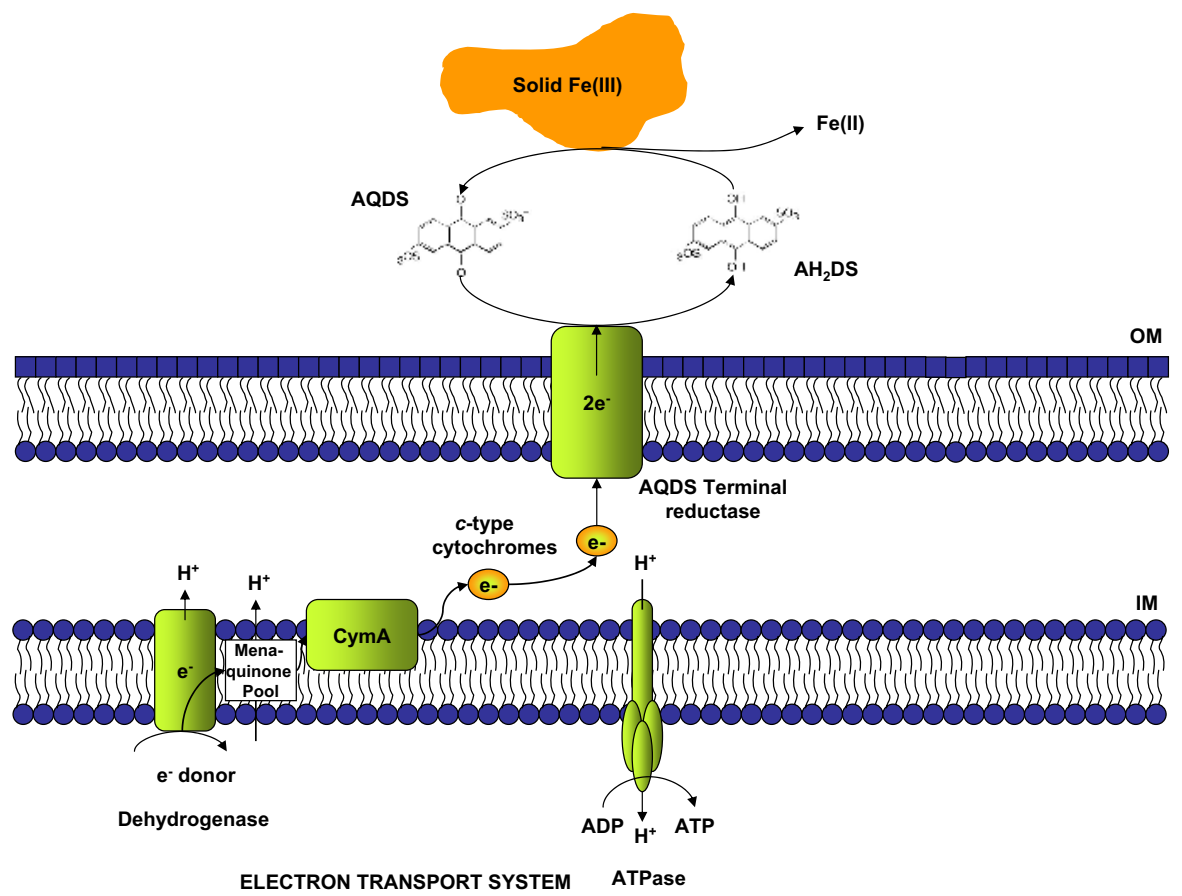

Figure 4. Working model for electron shuttling pathway with AQDS as electron shuttle. 
mutants (and corresponding membrane fractions) to reduce either $\mathrm{Fe}(\mathrm{III})$ or $\mathrm{Mn}$ (IV) (Saffarini et al. 2002). It should be noted that the endogenous electron shuttle pathway may be the consequence of cell lysis and inadvertent spillage of menaquinol into the culture medium. Since shuttles can undergo redox cycling they can be effective at low concentrations and therefore even a small fraction of cell lysis could have a significant effect. Lipid-soluble menaquinol or vitamin $\mathrm{K}_{2}$ then diffuses into bacterial membranes and functionally complements the men $B, C$ or $D$ mutants. Definitive evidence on the identity of the endogenous electron shuttle requires further research and will be challenging as exceedingly low concentrations may be involved.

\section{$\mathrm{Fe}$ (III) solubilization by exogenous or bacterially-produced organic ligands followed by reduction of soluble organic-Fe(III)}

A strong electrochemical signal indicative of soluble organic-Fe(III) is detected in a variety of marine and freshwater environments with $\mathrm{Au} / \mathrm{Hg}$ voltammetric microelectrodes (Taillefert et al. 2002). Soluble organic-Fe(III) may therefore represent a dominant, yet under appreciated electron acceptor in anaerobic aquatic systems. Microbial Fe(III) reduction rates are higher with soluble organic-Fe(III) in pure cultures of S. putrefaciens (Arnold et al. 1988) and in freshwater sediments amended with Fe(III)-chelating compounds such as nitrilotriacetic acid (Lovley and Woodward 1996). S. putrefaciens reduces soluble organic-Fe(III) complexes at rates three orders of magnitude faster than amorphous or crystalline Fe(III) forms (Arnold et al. 1988). The mechanism of formation of soluble organic-Fe(III) generally involves non-reductive dissolution of amorphous $\mathrm{Fe}$ (III) oxides by multidentate organic ligands (forming mononuclear complexes with the Fe(III) oxides) at circumneutral $\mathrm{pH}$. The strength of binding between $\mathrm{Fe}(\mathrm{III})$ and the complexing organic ligands influences soluble organic-Fe(III) reduction activity: organic ligands with strong $\mathrm{Fe}(\mathrm{III})$-binding capability decrease (and in some cases totally inhibit) $\mathrm{Fe}(\mathrm{III})$ reduction activity by $S$. putrefaciens (Haas and DiChristina 2002).

Some Fe(III)-reducing bacteria such as $S$. algae $\mathrm{BrY}$ and G. fermentans generate relatively high concentrations of soluble organic-Fe(III) in the absence of exogenous chelating compounds, an indication that such bacteria synthesize and release organic ligands to solubilize $\mathrm{Fe}(\mathrm{III})$ prior to reduction (Nevin and Lovley 2002). Soluble organic-Fe(III) is detected electrochemically in S. oneidensis and S. putrefaciens cultures incubated anaerobically with either ferrihydrite or goethite (Taillefert and DiChristina 2005). Detection of soluble organic$\mathrm{Fe}(\mathrm{III})$ prior to detection of $\mathrm{Fe}(\mathrm{II})$, suggests that soluble organic-Fe(III) is an intermediate in the reduction of solid Fe(III) oxides. Since lactate is the only organic ligand added to the Shewanella batch cultures and lactate-Fe(III) complexes do not react with $\mathrm{Au} / \mathrm{Hg}$ electrodes, electrochemical detection of soluble organic-Fe(III) suggests that Shewanella synthesizes and releases organic ligands that complex and dissolve Fe(III) prior to reduction. The identity of the bacterially-produced, Fe(III)-solubilizing organic ligands remains unknown.

A respiration-linked, soluble organic-Fe(III) terminal reductase has yet to be definitively identified. As described above, Shewanella Type II protein secretion mutants are unable to reduce solid $\mathrm{Fe}$ (III) oxides, yet retain the ability to respire all other electron acceptors, including soluble organic-Fe(III). This finding suggests that soluble organic-Fe(III) may be reduced by terminal reductases located in subcellular compartments other than the OM. The $S$. oneidensis decaheme $c$-type cytochrome MtrA is a candidate terminal reductase for soluble organic-Fe(III): MtrA is located in the S. oneidensis periplasm and displays soluble organicFe(III) reductase activity when expressed in E. coli (Pitts et al. 2003). The requirement for MtrA in anaerobic respiration of soluble organic-Fe(III), however, has yet to be demonstrated in vivo. In $S$. frigidimarina, the transcriptional activator IfcR is translated in the presence of soluble organic-Fe(III) and is essential for expression of if $\mathrm{O}$ and if $c A$. IfcO is a putative OM beta-barrel protein postulated to function as a soluble organic-Fe(III) transporter. IfcA is a flavin-containing $c$-type cytochrome with a small $(10 \mathrm{kDa})$ tetraheme cytochrome domain that 
displays soluble organic-Fe(III) reductase activity (Pitts et al. 2003). A working model of the two-step, Fe(III) solubilization-reduction pathway in Shewanella is displayed in Figure 5.

\section{ENZYMATIC BASIS OF URANIUM REDUCTION}

Members of the genera Shewanella (Lovley et al. 1991), Desulfovibrio (Lovley et al. 1993), Clostridium (Francis et al. 1994), Geobacter (Caccavo et al. 1992), Thermus (Kieft et al. 1999), Pyrobaculum (Kashefi and Lovley 2000), and Desulfosporosinus (Suzuki et al. 2002) display enzymatic U(VI) reduction activity. Shewanella and Geobacter enzymatically reduce $\mathrm{U}(\mathrm{VI})$ to $\mathrm{U}(\mathrm{IV})$ via a respiratory process that supports anaerobic growth. Although several purified $c$-type cytochromes display U(VI) reductase activity in vitro, a respirationlinked, U(VI) terminal reductase has yet to be definitively identified in vivo. Enzymatic U(VI) reduction activity is affected by $\mathrm{U}(\mathrm{VI})$ chemical speciation, electron donors, and competing electron acceptors. In the following section, the most recent findings on the enzymatic basis of U(VI) reduction by Shewanella and Geobacter are presented along with a discussion of the environmental factors affecting enzymatic U(VI) reduction activity.

\section{Involvement of $c$-type cytochromes in enzymatic $U(V I)$ reduction}

Cytochrome $c_{3}$ of several Desulfovibrio species is involved in electron transfer to U(VI). Cytochrome $c_{3}$ of U(VI)-reducing (but non-respiring) Desulfovibrio vulgaris Hildenborough displays $\mathrm{U}(\mathrm{VI})$ reductase activity in vitro with $\mathrm{H}_{2}$ as electron donor (Lovley et al. 1993). Cytochrome $c_{3}$ mutants of $D$. desulfuricans strain $\mathrm{G} 20$ are unable to reduce U(VI) with $\mathrm{H}_{2}$ as

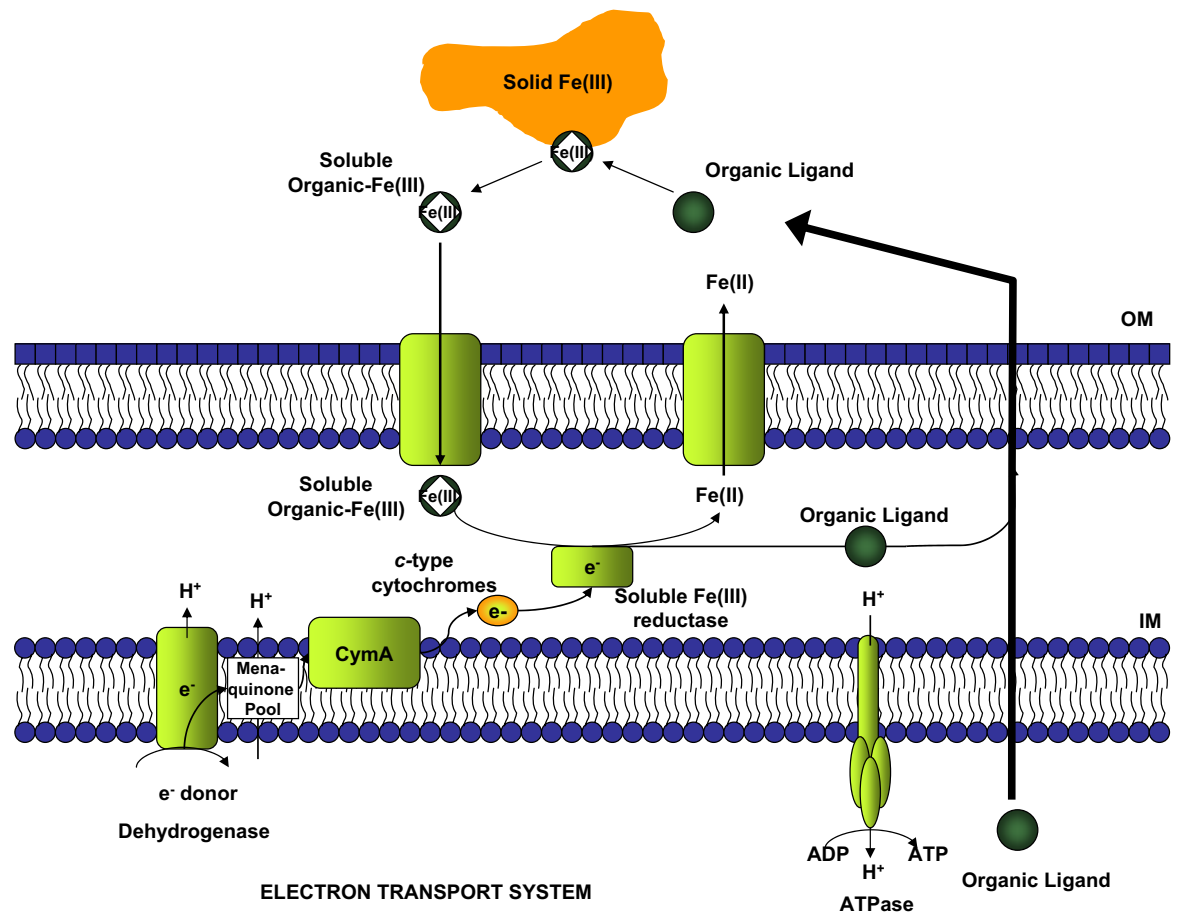

Figure 5. Working model for Fe(III) solubilization-reduction pathway with endogenous organic ligand as $\mathrm{Fe}(\mathrm{III})$-chelating compound. 
electron donor and are partially impaired in U(VI) reduction activity with lactate or pyruvate as electron donor (Payne et al. 2002). After growth of wild-type D. desulfuricans strain G20 in medium containing uranyl acetate, cytochrome $c_{3}$ is tightly associated with insoluble U(IV) particles (uraninite) found in the periplasm (Payne et al. 2004). Cytochrome $c_{7}$ of $G$. sulfurreducens also displays U(VI) reductase activity in vitro, however, mutants deficient in either cytochrome $c_{3}$ or $c_{7}$ retain U(VI) reduction activity in vivo (Lloyd et al. 2003). These findings suggest that either cytochrome $c_{3}$ and $c_{7}$ are not the physiological U(VI) reductases in G. sulfurreducens or that the electron transport pathway to U(VI) is highly branched and consists of multiple U(VI) terminal reductases. The highly branched nature of the U(VI) reduction pathway in G. sulfurreducens is reflected by the finding that $\mathrm{Fe}(\mathrm{III})$ reduction-deficient $p p c A$ mutants (see above) are also deficient in U(VI) reduction activity (Lloyd et al. 2003).

A genetic complementation system has recently been developed to examine the enzymatic mechanism of U(VI) reduction by S. putrefaciens (Wade and DiChristina 2000). S. putrefaciens respiratory mutants unable to reduce $\mathrm{U}(\mathrm{VI})$ have been isolated and tested for the ability to respire on a suite of alternate compounds as electron acceptor, including oxygen $\mathrm{O}_{2}, \mathrm{NO}_{3}{ }^{-}$, fumarate, trimethylamine- $N$-oxide (TMAO), dimethyl sulfoxide (DMSO), Mn(IV), Fe(III), chromate $(\mathrm{Cr}(\mathrm{VI}))$, arsenate $(\mathrm{As}(\mathrm{V}))$, selenite (Se(IV)), pertechnetate (Tc(VII)), thiosulfate (S(II)), and sulfite (S(IV)) (Wade and DiChristina 2000). All U(VI) reduction-deficient mutant strains also lacked the ability to respire $\mathrm{NO}_{2}{ }^{-}$. In particular, $\mathrm{U}(\mathrm{VI})$ reduction-deficient mutant strain $\mathrm{U} 14$ retained the ability to respire all electron acceptors except $\mathrm{U}(\mathrm{VI})$ and $\mathrm{NO}_{2}^{-}$. These results suggest that the electron transport chains terminating with the reduction of $\mathrm{NO}_{2}^{-}$and $\mathrm{U}(\mathrm{VI})$ share common respiratory components.

\section{Effect of $U(V I)$ chemical speciation on enzymatic $U(V I)$ reduction activity}

$\mathrm{U}(\mathrm{VI})$ chemical speciation is an important variable controlling enzymatic U(VI) reduction activity. In oxidizing aqueous environments at circumneutral $\mathrm{pH}$ (and in the absence of phosphate), $\mathrm{U}(\mathrm{VI})$ is found as soluble uranyl ion $\left(\mathrm{UO}_{2}{ }^{2+}\right)$, often in carbonate complexed form (e.g., $\left.\mathrm{UO}_{2}\left(\mathrm{CO}_{3}\right)_{2}{ }^{2-}, \mathrm{UO}_{2}\left(\mathrm{CO}_{3}\right)_{3}{ }^{4-}, \mathrm{CaUO}_{2}\left(\mathrm{CO}_{3}\right)_{2}{ }^{0}\right)$ or as crystalline solids such as metaschoepite $\left(\mathrm{UO}_{3} \cdot 2 \mathrm{H}_{2} \mathrm{O}\right)$, uranyl phosphates and uranyl silicates. U(IV) precipitates in reducing environments as uraninite $\left(\mathrm{UO}_{2}\right)$. The relative insolubility of $\mathrm{U}(\mathrm{IV})\left(10^{-8} \mathrm{M}\right.$ at $\mathrm{pH}$ $>$ 5; Rai et al. 1990) compared with U(VI) is the basis of alternate bioremediation strategies (Lovley et al. 1991). The uranyl ion readily complexes with either inorganic (e.g., hydroxyl, carbonate, phosphate, sulfate and calcium) or organic (e.g., acetate, malonate, citrate and oxalate) ligands in aqueous solution (Grenthe 1992), and complexation markedly enhances its solubility. The type of complexing ligand changes the reduction potential of U(VI) thus affecting enzymatic reduction activity. In terms of reduction potential, hydroxo complexes are the most easily reduced forms of complexed U(VI), while complexation by carbonate decreases the reduction potential of $\mathrm{U}(\mathrm{VI})$. Complexation of $\mathrm{U}(\mathrm{VI})$-carbonate by calcium (forming Ca$\mathrm{UO}_{2}-\mathrm{CO}_{3}$ complexes) decreases the reduction potential to such an extent that enzymatic U(VI) reduction by $S$. putrefaciens $\mathrm{CN} 32$ nearly ceases (Brooks et al. 2003). Enzymatic U(VI) reduction activity by $D$. desulfuricans and G. sulfurreducens is also inhibited by formation of $\mathrm{Ca}-\mathrm{UO}_{2}-\mathrm{CO}_{3}$ complexes. The effect of $\mathrm{Ca}^{2+}$ complexation on enzymatic $\mathrm{U}(\mathrm{VI})$ reduction activity are specific to $\mathrm{U}(\mathrm{VI})$ reduction since the enzymatic reduction of fumarate and $\mathrm{Tc}(\mathrm{VII})$ activities are not inhibited by $\mathrm{Ca}^{2+}$.

In the absence of carbonate or at $\mathrm{pH}<6$ in the presence of carbonate, organic ligands bound to $\mathrm{U}(\mathrm{VI})$ also dramatically impact enzymatic $\mathrm{U}(\mathrm{VI})$ reduction activity. Citrate, for example, binds $\mathrm{U}(\mathrm{VI})$ with varying strength as a function of $\mathrm{pH}$ (Pasilis and Pemberton 2003). At $\mathrm{pH}>6$ and at low citrate concentrations, the highly soluble $\left(\mathrm{UO}_{2}\right)_{3} \mathrm{Cit}_{2}$ species predominates over the $\left(\mathrm{UO}_{2}\right)_{2} \mathrm{Cit}_{2}$ species. $S$. alga $\mathrm{BrY}$ reduces $\mathrm{U}(\mathrm{VI})$ bound to citrate and other multidentate aliphatic complexes such as malonate and oxalate more rapidly than U(VI) 
bound to monodentate aliphatic complexes such as acetate, while the opposite trend is found with D. desulfuricans (Ganesh et al. 1997). U(VI) also adsorbs to carboxyl, phosphoryl and amine functional groups on the $S$. putrefaciens 200 cell surface, and a ligand exchange reaction may take place between the cell surface or U(VI) terminal reductases and the U(VI) complexes prior to reduction (Haas and DiChristina 2002).

\section{Electron donors and competing electron acceptors}

$\mathrm{U}(\mathrm{VI})$ reduction by Shewanella is coupled to oxidation of hydrogen, lactate, formate or pyruvate (Lovley et al. 1991). U(VI) reduction rates are highest with $\mathrm{H}_{2}$ as electron donor (Liu et al. 2002b). Two explanations have been proposed to account for the increased rate of $\mathrm{U}(\mathrm{VI})$ reduction coupled to $\mathrm{H}_{2}$ oxidation (Aubert et al. 2000; Liu et al. 2002b). First, electron flow through the electron transport chain may be more rapid when coupled to $\mathrm{H}_{2}$ rather than lactate oxidation. Periplasmic $\mathrm{H}_{2}$ hydrogenases may pass electrons through the electron transport chain more rapidly than those generated from cytoplasmic membrane-localized lactate dehydrogenase. Secondly, mass flux of neutrally charged $\mathrm{H}_{2}$ to the enzymatic site of oxidation may be faster than negatively charged lactate. The negative charge of the lactate ion inhibits diffusion across the cell surface to the cytoplasmic membrane, thereby requiring an active transport system.

The presence of competing terminal electron acceptors also interferes with microbial U(VI) reduction. Thermodynamic calculations predict that electron acceptors should be utilized in order of highest free energy yield, a possible explanation for the inhibition of U(VI) reduction in the presence of nitrate (Finneran et al. 2002). Although the reduction of U(VI) coupled to the oxidation of organic compounds should yield greater free energy than Fe(III) (Cochran et al. 1986), the half-cell potentials of both U(VI) and Fe(III) can vary markedly with their coordination environment and whether they exist in the form of aqueous complexes or solid phases. For example, the half-cell potentials at $\mathrm{pH} 7$ for many common, environmental $\mathrm{Fe}(\mathrm{III})$ forms vary from $+0.35 \mathrm{~V}$ to $-0.30 \mathrm{~V}$ (Stumm 1992), while those for U(VI) vary from $+0.284 \mathrm{~V}$ to $-0.042 \mathrm{~V}$ (Brooks et al. 2003). These variations in half-cell potential are compounded by the effects of reactant concentrations and other aqueous complexants, the similarity in half-cell potential of many Fe(III) and U(VI) forms and their uncertainty, the interfacial chemistry of solid phase electron acceptors, and the poorly understood redox chemistry of surface complexed Fe(II). All of these considerations complicate a rigorous thermodynamic analysis. The effects of $\mathrm{pH}$ are also strong because of the proton stoichiometry of reaction, and the redox stability of U(VI) over Fe(III), or vise-versa, may change if $\mathrm{pH}$ is not controlled, if reactant concentrations are varied appreciably, or if mineral biotransformation products exhibit different redox chemistry. In spite of these complexities and chemical interrelationships, there are some consistent thermodynamic observations. Ferrihydrite, with its higher redox potential $\left(\sim-0.070 \mathrm{~V}\right.$ at $\mathrm{pH}=7$ and $\left.\mathrm{Fe}(\mathrm{II})=10^{-5} \mathrm{~mol} / \mathrm{L}\right)$ was observed to inhibit bacterial $\mathrm{U}(\mathrm{VI})$ reduction, while goethite did not $\left(\sim-0.250 \mathrm{~V}\right.$ at $\mathrm{pH}=7$ and $\mathrm{Fe}(\mathrm{II})=10^{-5}$ $\mathrm{mol} / \mathrm{L}$ ) (Wielenga et al. 2000).

Electron transport to $\mathrm{Mn}(\mathrm{IV})$ provides a greater free energy yield than electron transport to $\mathrm{U}(\mathrm{VI})$, and is therefore predicted to be a preferred electron acceptor (Cochran et al. 1986; Langmuir 1997). Bioavailable Mn(IV)-oxides such as birnessite and bixbyite follow this prediction, however, U(VI) is reduced concurrently with less soluble forms of Mn(IV) (Fredrickson et al. 2002). To determine if this finding is due to electron acceptor competition or abiotic oxidation of U(IV) by Mn(IV), S. putrefaciens CN32 was incubated with U(VI) and pyrolusite $\left(\beta-\mathrm{MnO}_{2}\right)$ (Liu et al. 2002b). Extracellular, cell surface-associated, and periplasmic $\mathrm{UO}_{2}(\mathrm{~s})$ aggregates were detected by Transmission Electron Microscopy (TEM) when cells were incubated only with $\mathrm{U}(\mathrm{VI})$. Upon addition of pyrolusite, extracellular $\mathrm{UO}_{2}(\mathrm{~s})$ was depleted but periplasmic and cell surface-associated $\mathrm{UO}_{2}(\mathrm{~s})$ remained. These results suggest 
that U(IV) functions as an electron shuttle and is oxidized by the extracellular pyrolusite. $\mathrm{U}(\mathrm{VI})$ is completely reduced provided the $\mathrm{OM}$ of intact cells physically separates (sequesters in the periplasmic space) $\mathrm{UO}_{2}(\mathrm{~s})$ from extracellular pyrolusite.

Humic acids have recently gained attention for their potential role as shuttles for electron transfer between anaerobically respiring Shewanella and solid Fe(III)-oxides (see above). Addition of AQDS to $S$. putrefaciens $\mathrm{CN} 32$, however, does not enhance the reduction rate of either soluble or insoluble forms of U(VI) (Fredrickson et al. 2000). AQDS actually inhibits $\mathrm{U}(\mathrm{VI})$ reduction activity, possibly by diverting electrons away from the $\mathrm{U}(\mathrm{VI})$ reduction pathway.

\section{Subcellular location of enzymatic $\mathrm{U}(\mathrm{VI})$ reduction activity}

The subcellular location of enzymatic U(VI) reduction in Shewanella has also been recently examined: Insoluble U(IV) particles are detected extracellularly, on the cell surface and within the periplasmic space of $S$. putrefaciens $\mathrm{CN} 32$ after reduction of soluble U(VI) (Liu et al. 2002a). U(IV) is not detected in the cytoplasm (Fig. 6). U(VI) reductases may therefore be localized within the OM, diffuse (or be transported) across the OM to contact $\mathrm{U}(\mathrm{VI})$ reductases located in the periplasm or IM, or both. $\mathrm{U}(\mathrm{VI})$ reduction products of Desulfosporosinus have been detected as nanometer-sized $\mathrm{UO}_{2}(\mathrm{~s})$-particles (Suzuki et al. 2002). Nanoparticles produced in the periplasm either diffuse or are exported to the cell exterior where they organize extracellularly to form larger aggregates. Aggregation of U(IV) particles prior to export from the cell may result in the periplasmic deposits detected on TEM images of U(VI)-respiring cells (Liu et al. 2002a). U(IV) particles detected in the culture supernatant also leads to the intriguing possibility that anaerobically-respiring Shewanella are able to actively secrete U(IV) particles as a means of avoiding build-up of toxic insoluble $\mathrm{U}(\mathrm{IV})$ end-products during $\mathrm{U}(\mathrm{VI})$ reduction. $S$. putrefaciens $\mathrm{CN} 32$ is also capable of reducing solid forms of U(VI) such as metaschoepite (Fredrickson et al. 2000), although solid forms of $\mathrm{U}(\mathrm{VI})$ have been found to be resistant to microbial reduction in situ (Ortiz-Bernad et al. 2004). The mechanism by which Shewanella species reduce metaschoepite is unknown, but U(VI) terminal reductase localization to the $\mathrm{OM}$ to contact solid $\mathrm{U}(\mathrm{VI})$ is possible.

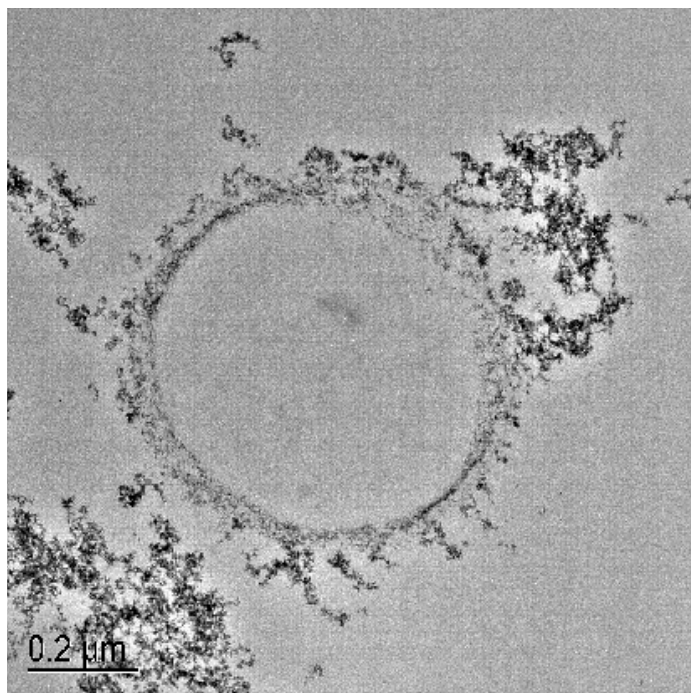

Figure 6. Transmission electron microscopy image of an unstained thin section from Shewanella putrefaciens strain $\mathrm{CN} 32$ cells incubated with $\mathrm{H}_{2}$ and $\mathrm{U}(\mathrm{VI})$ in $\mathrm{pH}$ 7 bicarbonate buffer, illustrating the accumulation of nano-size $\mathrm{U}(\mathrm{IV}) \mathrm{O}_{2}$ particles extracellularly and in association with the periplasmic space and cell surface. 


\section{ENZYMATIC MECHANISM OF TECHNETIUM REDUCTION}

Enzymatic studies on Tc(VII) reduction have largely been focused in E. coli, however the ability to reduce Tc(VII) has been recently found in $S$. putrefaciens $\mathrm{CN} 32$, S. oneidensis MR-1 and S. putrefaciens 200 (Lyalikova and Khizhnyak 1996; Lloyd et al. 1997; Wildung et al. 2000; Payne and DiChristina 2005). Tc(VII) is also reduced under acidic conditions by Thiobacillus thiooxidans (Lyalikova and Khizhnyak 1996), under alkaline conditions by Halomonas strain Mono (Khijniak et al. 2003) and at high temperature by Pyrobaculum islandicum (Kashefi and Lovley 2000). Reduction of soluble Tc(VII) results in formation of $\mathrm{Tc}(\mathrm{IV})$ which precipitates as insoluble $\mathrm{TcO}_{2} \cdot n \mathrm{H}_{2} \mathrm{O}$ (hereafter termed $\mathrm{TcO}_{2}$ ) and may be immobilized in situ. In the absence of aqueous complexing agents, Tc(IV) may also be immobilized via formation of strong surface complexes with hydroxylated surface sites on $\mathrm{Al}$ and Fe oxides and clays (Rard 1983; Haines et al. 1987; Meyer et al. 1991; Eriksen et al. 1992; Wildung et al. 2000).

\section{Involvement of hydrogenases in $\mathrm{Tc}$ (VII) reduction}

E. coli possesses four hydrogenases, designated as hydrogenases 1-4. Hydrogenases-1 and 2 share little homology to hydrogenases-3 and 4. Hydrogenases 3 and 4 share high homology to each other and are both expressed as part of the formate-hydrogen lyase complex in $E$. coli (Bagramyan and Trchounian 2003). The Tc(VII) reductase in E. coli has been identified as the Ni-Fe hydrogenase-3 component of the formate-hydrogen lyase complex (Lloyd et al. 1997). Hydrogenase expression is determined by $\mathrm{pH}$ : hydrogenase- 4 (encoded by the hyf operon) is expressed under alkaline conditions while hydrogenase-3 (encoded by the hyc operon) is expressed under acidic conditions (Bagramyan and Trchounian 2003). The formate-hydrogen lyase complex in E. coli is composed of formate dehydrogenase plus multiple components of the respective hydrogenase encoding operons (i.e., hyf and hyp operons). The bi-directional nature of hydrogenase-3 (HycE) enables both the production of $\mathrm{H}_{2}$ during formate oxidation and the direct oxidation of $\mathrm{H}_{2}$ under other conditions.

S. oneidensis MR-1 does not possess a formate-hydrogen lyase complex and possesses only two hydrogenases, neither of which share significant homology to hydrogenases-3 or 4 of E. coli. The first S. oneidensis MR-1 hydrogenase (Locus SO2098; HyaB) displays high homology to the IM-bound $\mathrm{Ni}-\mathrm{Fe}$ hydrogenase $\mathrm{HydB}$ of Wolinella succinogenes, while the second S. oneidensis MR-1 hydrogenase (Locus SO3920; HydA) displays high homology to the putative D subunit of the NADP-reducing hydrogenase of Thermotoga maritima (Payne and DiChristina 2005). In terms of hydrogenase function, $S$. oneidensis MR-1 hydrogenases appear most similar to those of Alcaligenes eutrophus in which the cytoplasmic, soluble hydrogenase (HydA) regenerates $\mathrm{NADH}$, while the membrane bound $\mathrm{Ni}-\mathrm{Fe}$ hydrogenase (HyaB) generates reducing power (Lengeler et al. 1999). In organisms containing only membrane bound hydrogenases, reducing power is generated by reverse electron transport, generally carried out by membrane bound bi-directional hydrogenases (e.g., hydrogenases3 and 4 in E. coli). S. oneidensis MR-1 therefore appears to share close similarity to the hydrogen uptake and utilization systems of A. eutrophus and little sequence or physiological similarity to the $\mathrm{H}_{2}$ uptake and utilization systems of $E$. coli. Further work needs to be carried out to determine if the $S$. oneidensis MR-1 hydrogenases display $\mathrm{Tc}(\mathrm{VII})$ reductase activity.

\section{Subcellular location of enzymatic Tc(VII) reduction activity}

The enzymatic reduction of $\mathrm{Tc}(\mathrm{VII})$ is electron donor-specific. $\mathrm{H}_{2}$ serves as electron donor in all known Tc(VII)-reducing organisms (Lloyd et al. 2000; Wildung et al. 2000; De Luca et al. 2001), while the ability to couple the oxidation of other carbon sources to the reduction of Tc(VII) occurs in only a small subset of organisms. G. sulfurreducens and $D$. 
fructosovorans have an exclusive requirement for $\mathrm{H}_{2}$ as electron donor for $\mathrm{Tc}(\mathrm{VII})$ reduction while E. coli is limited to formate and $\mathrm{H}_{2}$ as electron donor. S. oneidensis MR-1 and $S$. putrefaciens CN32 couple the oxidation of formate, lactate, and $\mathrm{H}_{2}$ to $\mathrm{Tc}(\mathrm{VII})$ reduction (Wildung et al. 2000; Payne and DiChristina 2005), but Tc(VII) reduction rates are markedly higher with $\mathrm{H}_{2}$ as electron donor. The reduced Tc(IV) product is generally nanometer-sized $\mathrm{TcO}_{2(\mathrm{~s})}$ in buffers or media without high carbonate. The identity of the electron donor does not seem to influence the mineralogic nature of the reduction product. The black-colored precipitate is observed in the periplasm, and as $20-50 \mathrm{~nm}$ dome-like structures consisting of aggregates of many individual crystallites on the cell surface (Fig. 7). The $\mathrm{TcO}_{2(\mathrm{~s})}$ is nanocrystalline and exhibits insufficient long-range order to yield a discernable diffraction pattern. The precipitate maintains a Tc solubility $\left(\approx 10^{-8} \mathrm{~mol} / \mathrm{L}\right)$ that approximates measured values for $\mathrm{TcO}_{2} \cdot x \mathrm{H}_{2} \mathrm{O}$ (as reported by Rard 1999 and associated citations). The physiologic relationship between subcellular and surface associated $\mathrm{TcO}_{2(\mathrm{~s})}$ is unclear. Limited evidence implies that bioreduced Tc [e.g., Tc(IV)] may exist in the form of carbonate aqueous complexes, or perhaps carbonate precipitates, in high-bicarbonate media (Wildung et al. 2000). Further research on the biogeochemistry of $\mathrm{Tc}(\mathrm{VII}) / \mathrm{Tc}(\mathrm{IV})$ in bicarbonate-containing media and other ligand solutions of geochemical relevance is needed.
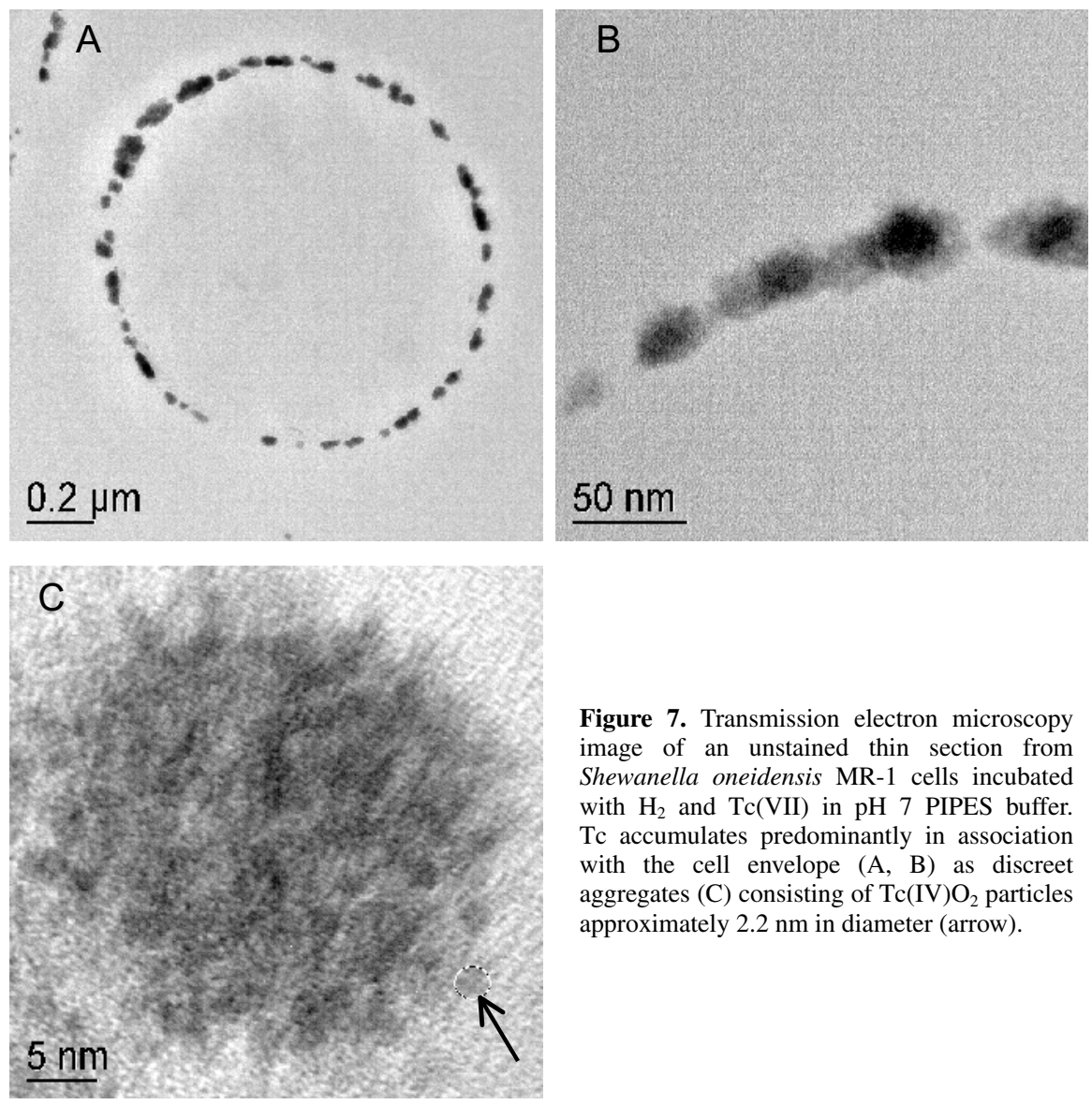

Figure 7. Transmission electron microscopy image of an unstained thin section from Shewanella oneidensis MR-1 cells incubated with $\mathrm{H}_{2}$ and $\mathrm{Tc}(\mathrm{VII})$ in $\mathrm{pH} 7$ PIPES buffer. Tc accumulates predominantly in association with the cell envelope (A, B) as discreet aggregates (C) consisting of $\mathrm{Tc}(\mathrm{IV}) \mathrm{O}_{2}$ particles approximately $2.2 \mathrm{~nm}$ in diameter (arrow). 


\section{MICROBIAL REDUCTION-INDUCED CHANGES IN METAL BIOGEOCHEMISTRY}

\section{Direct enzymatic effects of dissimilatory metal-reducing bacteria (DMRB) on metal solubility}

The majority of electron acceptors commonly used by prokaryotes (oxygen, nitrate, sulfate, carbon dioxide) exhibit relatively high levels of solubility before and after reduction. In contrast, many of the metals used as microbial electron acceptors exhibit substantially different solubility properties in the oxidized (e.g., $\mathrm{p} \varepsilon=10)$ versus the reduced $(\mathrm{p} \varepsilon=4$ or 2$)$ states (Table 1). Because Fe(III) and Mn(III,IV) exist predominantly as oxyhydroxide minerals in oxic environments (e.g., ferrihydrite and goethite, or birnessite and manganite), DMRB must overcome the fundamental problem of engagement of the cell electron transport system (ETS) with the mineral surface across a solid-liquid interface. DMRB have developed several novel mechanisms for overcoming this problem, as described in preceding sections, including the "shuttling" of electrons by humic acids (Lovley et al. 1996; Lovley and Woodward 1996) or cell metabolites (Newman and Kolter 2000) from terminal points of the ETS to the mineral surfaces, possibly the direct transfer of electrons to metal in the centers of mineral surfaces by multiheme cytochromes associated with the OM (Richardson 2000; Leang et al. 2003), or the solubilization of solid phase-associated $\mathrm{Fe}(\mathrm{III})$ as subsequent engagement of $\mathrm{Fe}(\mathrm{III})$ reductase(s) as a soluble $\mathrm{Fe}(\mathrm{III})$-organic complex. Regardless of the mechanism, the microbial reduction of $\mathrm{Fe}$ and $\mathrm{Mn}$ has a profound impact on the geochemical behavior of these metals as

Table 1. Solubilities (aqueous concentrations) of select phases of $\mathrm{Fe}, \mathrm{Mn}, \mathrm{U}$, and $\mathrm{Tc}$ at $\mathrm{pH} 7 \mathrm{in}$ water as a function of $p \mathrm{e}\left(\mathrm{pCO}_{2}=10^{-3.46} \mathrm{~atm}, I=0.01\right)$.

\begin{tabular}{|c|c|c|c|}
\hline \multirow[t]{2}{*}{ Solid phase } & \multirow{2}{*}{$\begin{array}{c}\text { Oxidizing } \\
\mathrm{p} \varepsilon=10 \\
\mathrm{~mol} / \mathrm{L}\end{array}$} & \multicolumn{2}{|c|}{$\underline{\text { Reducing }}$} \\
\hline & & $\begin{array}{l}(\mathrm{p} \varepsilon=4) \\
\mathrm{mol} / \mathrm{L}\end{array}$ & $\begin{array}{c}(\mathrm{p} \varepsilon=2) \\
\mathrm{mol} / \mathrm{L}\end{array}$ \\
\hline $\mathrm{Fe}(\mathrm{OH})_{3}$ (ferrihydrite) & $2.06 \times 10^{-8}\left(\mathrm{Fe}^{3+}\right)$ & $\begin{array}{l}2.06 \times 10^{-8}\left(\mathrm{Fe}^{3+}\right) \\
1.29 \times 10^{-7}\left(\mathrm{Fe}^{2+}\right)\end{array}$ & $\begin{array}{l}2.06 \times 10^{-8}\left(\mathrm{Fe}^{3+}\right) \\
1.29 \times 10^{-5}\left(\mathrm{Fe}^{2+}\right)\end{array}$ \\
\hline$\alpha-\mathrm{FeOOH}$ (goethite) & $8.40 \times 10^{-13}\left(\mathrm{Fe}^{3+}\right)$ & $\begin{array}{l}8.36 \times 10^{-13}\left(\mathrm{Fe}^{3+}\right) \\
5.24 \times 10^{-12}\left(\mathrm{Fe}^{2+}\right)\end{array}$ & $\begin{array}{l}8.36 \times 10^{-13}\left(\mathrm{Fe}^{3+}\right) \\
5.24 \times 10^{-10}\left(\mathrm{Fe}^{2+}\right)\end{array}$ \\
\hline $\mathrm{MnO}_{1.8}$ (birnessite) & $6.03 \times 10^{-5}\left(\mathrm{Mn}^{2+}\right)$ & Soluble as $\mathrm{Mn}^{2+\mathrm{a}}$ & Soluble a \\
\hline$\gamma$-MnOOH (manganite) & $2.87 \times 10^{-6}\left(\mathrm{Mn}^{2+}\right)$ & $\begin{array}{c}\text { Soluble as } \mathrm{Mn}^{2+\mathrm{a}} \\
(2.83 \mathrm{~mol} / \mathrm{L} \text { maximum })\end{array}$ & Soluble ${ }^{a}$ \\
\hline $\mathrm{UO}_{2}$ (uraninite) & $2.67 \times 10^{-7}\left[\mathrm{U}(\mathrm{VI}) \mathrm{O}_{2}{ }^{2+}\right]^{\mathrm{b}}$ & $2.67 \times 10^{-7}\left[\mathrm{U}(\mathrm{VI}) \mathrm{O}_{2}{ }^{2+}\right]^{\mathrm{b}}$ & $\begin{array}{c}1.46 \times 10^{-7}\left[\mathrm{U}(\mathrm{VI}) \mathrm{O}_{2}{ }^{2+}\right] \\
2.0 \times 10^{-17}\left[\mathrm{U}(\mathrm{IV})(\mathrm{OH})_{4(\mathrm{aq})}\right]^{\mathrm{c}}\end{array}$ \\
\hline $\mathrm{TcO}_{2} \cdot n \mathrm{H}_{2} \mathrm{O}$ & Soluble as $\mathrm{Tc}(\mathrm{VII}) \mathrm{O}_{4}^{-}$ & Soluble as $\mathrm{Tc}(\mathrm{VII}) \mathrm{O}_{4}^{-}$ & $10^{-8}\left[\mathrm{Tc}(\mathrm{IV}) \mathrm{O}(\mathrm{OH})_{2(\mathrm{aq})}\right]$ \\
\hline
\end{tabular}

a. Will precipitate as rhodochrosite $\left[\mathrm{MnCO}_{3(\mathrm{c})}\right]$

b. $1 \times 10^{-4} \mathrm{~mol} / \mathrm{L}$ precipitated as schoepite $\left[\beta-\mathrm{UO}_{3} \cdot 2 \mathrm{H}_{2} \mathrm{O}_{(\mathrm{c})}\right]$, the primary aqueous complex under the given conditions is $\mathrm{UO}_{2}\left(\mathrm{CO}_{3}\right)_{2}{ }^{2-}$, solubility increases with $\mathrm{CO}_{2(\mathrm{~g})}$ partial pressure and total aqueous carbonate concentration

c. $9.98 \times 10^{-5} \mathrm{~mol} / \mathrm{L}$ precipitated as uraninite $\left[\mathrm{UO}_{2(\mathrm{c})}\right], \mathrm{p} \varepsilon$ is $1.8, \mathrm{U}(\mathrm{VI})$ concentrations decrease with decreasing $\mathrm{p} \varepsilon$. 
well as broader impacts on the overall geochemical and mineralogic properties of solids and sediments where these processes occur.

In contrast to $\mathrm{Fe}$ and $\mathrm{Mn}, \mathrm{U}, \mathrm{Tc}$, and $\mathrm{Cr}$ are relatively soluble in oxic environments and typically exist as anionic uranyl carbonate $\mathrm{UO}_{2}\left(\mathrm{CO}_{3}\right)_{3}{ }^{4-}, \mathrm{UO}_{2}\left(\mathrm{CO}_{3}\right)_{2}{ }^{2-}$ complexes, pertechnetate $\left(\mathrm{TcO}_{4}{ }^{-}\right)$, or chromate $\left(\mathrm{CrO}_{4}{ }^{2-}\right)$, respectively. The solubility of $\mathrm{U}(\mathrm{VI})$ at circumneutral $\mathrm{pH}$ is strongly dependent on dissolved carbonate concentration and other associated ligands such as silica or phosphate. Upon reduction to the +4 oxidation state and in the absence of strong complexants, $\mathrm{U}$ and $\mathrm{Tc}$ can precipitate as the hydrous oxides, $\mathrm{UO}_{2}$ (uraninite) and $\mathrm{TcO}_{2}$, phases that have been identified in anaerobic suspensions of DMRB cells incubated with U(VI) (Gorby and Lovley 1992) or Tc(VII) (Wildung et al. 2000) and appropriate electron donors. The direct enzymatic reduction of $\mathrm{U}(\mathrm{VI})$ results in the formation of relatively uniformly-sized nanoparticles (Fredrickson et al. 2002; Suzuki et al. 2002), a factor that can impact their subsequent reactivity and transport. For example, if U(IV) nanoparticles are less than approximately 2-to-5 $\mathrm{nm}$ in diameter, they may behave as large molecular clusters and be mobile in solution, while U(IV) particles with larger diameters may not be transported as readily (as described in chapter on nanoparticles by Gilbert and Banfield 2005). It is these marked changes in solubility that have prompted consideration of manipulating the activities of DMRB for the bioremediation of soils and sediments contaminated with metals and radionuclides (Lovley 1995).

\section{Indirect effects of DMRB on metal solubility}

DMRB can also indirectly influence the biogeochemical behavior of redox active and non-redox active metals. Because the mass content of Fe and $\mathrm{Mn}$ is typically higher than trace metals and contaminants in most soils and sediments they tend to have a dominant effect on redox reactions and function as a major sink for electrons from DMRB respiration. Due to their relatively higher mid-point potential, Mn oxides can provide a "buffer" against the net reduction of other metal ions including Fe(III) (Lovley and Phillips 1988; Myers and Nealson 1988) and U(VI) (Liu et al. 2002b). Because Mn(III,IV) oxides are relatively strong oxidants they can also oxidize reduced forms of metals such as $\mathrm{Cr}(\mathrm{OH})_{3}$ (Fendorf and Zasoski 1992) and $\mathrm{UO}_{2}$ (Fredrickson et al. 2002), hence impeding their net microbial reduction unless there are mechanisms that prevent their physical interaction such as the accumulation and isolation of $\mathrm{UO}_{2}$ nanoparticles in the cell periplasm (Fredrickson et al. 2002). Although Fe(III) oxides are not as effective oxidants as Mn oxides, they can potentially impede the reduction of other metals such as U(VI) via competition mechanisms (Wielinga et al. 2000). Hence, the microbial reduction of $\mathrm{Mn}$ and $\mathrm{Fe}$ oxides can result in redox conditions that are more favorable for the reduction for trace metal contaminants. In addition, $\mathrm{Fe}(\mathrm{II})$ and $\mathrm{Mn}$ (II) can potentially provide buffer against re-oxidation.

Biogenic Fe(II) can also function as a facile reductant of trace metal and radionuclides including U(VI) (Liger et al. 1999), Tc(VII) (Lloyd et al. 2000; Wildung et al. 2004), and $\mathrm{Cr}(\mathrm{VI})$ (Wielinga et al. 2001). The rate of $\mathrm{Tc}(\mathrm{VII}) \mathrm{O}_{4}{ }^{-}$reduction by sediment-associated biogenic Fe(II) was shown to be related directly to the extent of sediment Fe(III) reduction but there was extensive variation among different sediments indicating that the effectiveness of $\mathrm{Fe}(\mathrm{II})$ as a reductant was highly dependent upon molecular speciation as opposed to $\mathrm{Fe}(\mathrm{II})$ concentration alone (Fredrickson et al. 2004; Hansel et al. 2004). In general, aqueous Fe(II) is poorly reactive with Tc(VII) (Cui and Eriksen 1996) and U(VI) (Fredrickson et al. 2000), probably due to kinetic limitations. In contrast, the rates of chromate reduction by $\mathrm{Fe}(\mathrm{II})_{\mathrm{aq}}$ are relatively rapid (Wielinga et al. 2001). One area that warrants further investigation is whether biosorbed Fe(II), which can form complexes and precipitates on cell surfaces (Liu et al. 2001a), can also function as a reductant in a manner similar to Fe(II) sorbed on mineral surfaces. The fact that $\mathrm{Fe}$ oxides can impede i.e., via competition (Wielinga et al. 2000) 
or promote, i.e., via surface complexation of Fe(II) (Fredrickson et al. 2004), reflects the similarity of the mid-point potentials of these metals and the need to pay careful attention to factors including speciation, concentration, and solubility that can greatly impact the direction and extent of such redox reactions.

Trace metals can associate with Fe or Mn oxides as adsorbed or co-precipitated species and are therefore subject to biogeochemical reactions resulting from utilization of the oxide as a terminal electron acceptor by DMRB. $\mathrm{Ni}^{2+}$ and $\mathrm{Co}^{2+}$ co-precipitated with goethite were released when oxide suspensions were subject to reduction by $S$. putrefaciens CN32, resulting in a net increase in aqueous concentrations of the metal ions (Zachara et al. 2001). Similarly, $\mathrm{Ni}^{2+}$ was also released from a Ni-substituted hydrous ferric oxide upon reduction by strain $\mathrm{CN} 32$ although under select conditions a Ni-substituted magnetite $\left(\mathrm{Fe}^{\mathrm{III}}{ }_{2} \mathrm{Fe}^{\mathrm{II}}{ }_{1-x} \mathrm{Ni}_{x} \mathrm{O}_{4}\right)$ formed (Fredrickson et al. 2001). $\mathrm{Ni}^{2+}$ was found to inhibit the overall reduction reaction by an undefined chemical mechanism that could be circumvented by addition of AQDS as an electron shuttle. Aluminum release during the bioreduction of an Al-substituted goethite associated with an Atlantic coastal plain sediment was congruent with the production of $\mathrm{Fe}$ (II) but the released Al was associated with a sorbed phase (Kukkadapu et al. 2001). DMRB can also promote the mobilization of arsenic as arsenate via the reductive dissolution of the ferric arsenate mineral scorodite $\left(\mathrm{FeAsO}_{4} \cdot 2 \mathrm{H}_{2} \mathrm{O}\right)$ and from iron oxide sorption sites within sediments (Cummings et al. 1999). It is interesting to note that some DMRB are also capable of dissimilatory reduction of arsenate (AsV) to arsenite (AsIII) (Saltikov et al. 2003) but such a reduction reaction was not observed. Although there is considerable potential for mobilization of trace elements associated with metal oxides during bioreduction, the extent to which trace metals remain associated with the solid phase or are released to solution will be a function of the aqueous and solid-phase geochemical composition that ultimately controls the adsorption and precipitation reactions.

\section{REDUCTIVE TRANSFORMATION OF Fe- AND Mn-CONTAINING MINERALS}

The rate and extent of microbial reduction of Fe(III) and Mn (III,IV) oxides in soils and sediments is a function of complex and highly coupled biological, chemical, and physical factors. Mineralogy plays a critical role with factors such as surface area (Roden and Zachara 1996), extent of structural disorder (Zachara et al. 1998), surface speciation (Roden and Urrutia 2002), and thermodynamics (Liu et al. 2001b) all influencing, to some extent, the reduction process. The physiological state of the organisms, including effects resulting from growth medium composition (Glasauer et al. 2003) and electron donor-acceptor ratios (Zachara et al. 2002), are other key variables that can affect bioreduction of Fe and Mn minerals but are currently poorly understood. The role of cell physiology on metal oxide reduction is currently under-appreciated and its importance warrants further research using physiologically and compositionally defined cultures that better represent and span the range of environmental conditions.

\section{Laboratory studies}

A general observation made from laboratory studies is that poorly crystalline $\mathrm{Fe}(\mathrm{III})$ oxides such as ferrihydrite (Lovley and Phillips 1986) exhibit a greater degree of bioavailability than more crystalline phases such as lepidocrocite $(\gamma-\mathrm{FeOOH})$, goethite $(\alpha-\mathrm{FeOOH})$, or hematite $\left(\mathrm{Fe}_{2} \mathrm{O}_{3}\right)$, although as a crystalline phase, lepidocrocite is far more bioavailable than the others. The same general trend appears to hold true for Mn oxides in that more highly crystalline phases such as pyrolusite $\left(\beta-\mathrm{MnO}_{2}\right)$ are reduced more slowly than amorphous $\mathrm{MnO}_{2}$ or birnessite (Burdige et al. 1992). This effect has been attributed to differences in solubility of these phases and is supported by experiments demonstrating that the maximum rate of $\mathrm{Fe}$ (III) reduction was found to correlate positively with the solubility of the oxide (Bonneville et al. 2004). Caution must be exercised when using rates of abiotic reduction of Fe oxides as an 
indicator of their susceptibility to enzymatic reduction as the surface area-normalized rates of bacterial reduction of ferrihydrite, lepidocrocite, goethite, and hematite were found to be quite similar, in contrast to reduction of the same phases by ascorbic acid (Roden 2003). Naturallyoccurring (geologic) Fe oxides have been found to be equally or more reducible than their synthetic counterparts with crystalline disorder and microheterogeneities potentially being dominant factors controlling microbial reduction (Zachara et al. 1998).

The presence of solid phase sorbents and organic complexants can also facilitate microbial reduction of $\mathrm{Fe}$ oxides, presumably via the removal of reduction product $\left(\mathrm{Fe}^{2+}\right)$ from oxide and bacterial surfaces (Urrutia et al. 1999). A similar enhancement in the extent of Fe oxide reduction can be achieved by continual replacement of the aqueous phase in semi-continuous cultures (Roden and Urrutia 1999) or in continuous flow columns where soluble Fe(II) is constantly removed (Roden et al. 2000). The products of oxide bioreduction can hence impede further reduction by passivating oxide and cell surfaces (Liu et al. 2001a,b) or can promote reduction by removing products from solution via secondary precipitation reactions.

Transformation of Fe- and Mn-bearing minerals to secondary phases is similarly a function of a complex set of biogeochemical variables. A number of laboratory studies have probed the bioreductive transformation of poorly crystalline ferrihydrites to a wide range of phases including more highly ordered Fe(III) oxides such as 6-line ferrihydrite, goethite, lepidocrocite (Zachara et al. 2002, Fredrickson et al. 2003; Hansel et al. 2003; Kukkadapu et al. 2003, 2005), mixed valence oxides such as magnetite and green rust $\left.\left[\mathrm{Fe}_{(6-x)}^{\mathrm{II}} \mathrm{Fe}_{(x)}{ }^{\mathrm{III}}(\mathrm{OH})_{12}\right]^{x+}\left[\left(A^{2-}\right)_{x / 2} \cdot y \mathrm{H}_{2} \mathrm{O}\right]^{x-}\right]$ (Lovley et al. 1987; Fredrickson et al. 1998), or $\mathrm{Fe}(\mathrm{II})$ phases including siderite $\left(\mathrm{FeCO}_{3}\right)$, vivianite $\left(\mathrm{Fe}_{3}\left(\mathrm{PO}_{4}\right)_{2} \cdot 8 \mathrm{H}_{2} \mathrm{O}\right)$, and ferrous hydroxy carbonate $\left(\mathrm{Fe}_{2}(\mathrm{OH})_{2} \mathrm{CO}_{3}\right)$ (Fredrickson et al. 1998; Hansel et al. 2003; Kukkadapu et al. 2003). The extent to which each of these phases may form is influenced by a range of factors including $\mathrm{pH}$ and aqueous solution composition (Fredrickson et al. 1998), the relative concentrations of the oxide (electron acceptor) and electron donor (Zachara et al. 2002; Fredrickson et al. 2003), the presence of co-precipitated ions (Fredrickson et al. 2001; Kukkadapu et al. 2004), and hydrodynamic-induced distributions of reduction products (Hansel et al. 2003). The formation of secondary mineral phases is less common or extensive when more highly ordered phases such as hematite or goethite are reduced by DMRB but nonetheless Fe(II) biominerals such as siderite and vivianite have been observed to form under conditions consistent with their solubility (Zachara et al. 1998). The lower solubility of more highly ordered phases such as goethite and hematite support lower concentrations of $\mathrm{Fe}(\mathrm{III})_{\mathrm{aq}}$ and DMRB-generated $\mathrm{Fe}(\mathrm{II})_{\mathrm{aq}}$, relative to ferrihydrite, and therefore hinder precipitation of secondary minerals such as magnetite beyond reorganization on the mineral surface into nanometer-size spinel-like domains (Hansel et al. 2004).

In addition to $\mathrm{Fe}$ oxides and oxyhydroxides, $\mathrm{DMRB}$ can also reduce structural $\mathrm{Fe}$ in clay minerals facilitating their dissolution (Kostka et al. 1996, 1999) or changes in clay morphology, structure, and composition (Dong et al. 2003a,b). The extent of microbial reduction of structural $\mathrm{Fe}$ (III) in smectite can be substantial, ranging to $>90 \%$ (Kostka et al. 1999). The microbial reduction of structural Fe in clay can significantly alter clay chemical and physical properties such as was reported for studies with smectite where reduction resulted in reduced swelling pressure, total surface area, and surface charge density (Kostka et al. 1999). Structural Fe(II) in bioreduced ferruginous clays can also promote the reductive dehydrochlorination of organic contaminants such as pentachloroethane and trichloroethane (Cervini-Silva et al. 2003).

\section{Field studies}

Controlled single-phase, single organism laboratory experiments can provide important mechanistic insights but it is often difficult to predict field behavior from such results due to environmental complexities and heterogeneities. One of the more well studied field sites is 
a crude oil-impacted shallow groundwater aquifer located near Bemidji, Minnesota, USA. Research at this site has documented aspects of microbial community structure (Rooney-Varga et al. 1999) and associated geochemical changes (Baedecker et al. 1993) over the length of the plume as the predominant respiratory process shifted from Fe(III) and Mn(III,IV) reduction to methanogenesis (Anderson and Lovley 1999). A detailed analysis of sediments from within the plume and from the pristine aquifer revealed significant differences in the mass content and identify of $\mathrm{Fe}$ (III) oxides consistent with microbial-driven reduction processes (Zachara et al. 2004). Comparisons between the texturally-similar source where bioavailable Fe(III) had been exhausted and $\mathrm{Fe}(\mathrm{III})$-reducing zone sediments where bioavailable $\mathrm{Fe}(\mathrm{III})$ remained indicated that dispersed crystalline $\mathrm{Fe}$ (III) oxides and a portion of the poorly crystalline $\mathrm{Fe}$ (III) oxide fraction had been depleted from the source zone sediment. The presence of residual ferrihydrite in the anoxic plume sediment indicated that some fraction of the $\mathrm{Fe}$ (III) oxides were biologically inaccessible, possibly due to their residence in microfractures in the interior of lithic fragments. Interestingly, little evidence was found for biogenic ferrous mineral phases with the exception of thin siderite or ferroan calcite surface precipitates. It is clear that additional field-based research including characterization of samples in concert with modeling and laboratory-based experiments is needed to improve our ability to predict biogeochemical behavior of redox active metals in natural and engineered systems, particularly with regard to mineral biotransformation products and biominerals.

\section{ROLE OF MICROBIAL METAL REDUCTION IN REDOX CYCLING}

As is the case for most microorganisms, DMRB rarely function alone but are members of complex communities whose collective, intertwined activities are responsible for catalyzing the cycling of elements in the biosphere. Many DMRB, particularly members of the genus Shewanella, are well-adapted to geochemically stratified environments where there is a gradient in electron acceptors available for oxidizing organic matter and $\mathrm{H}_{2}$. These adaptations include a relatively robust and diverse electron transport system that can engage a wide range of electron acceptors and an extensive network of regulatory genes, both two-component and transcriptional regulators (Heidelberg et al. 2002), that allow the organisms to sense and respond to their environment. These organisms play a critical role in such environments by oxidizing fermentation products, such as low molecular weight organic acids, coupled to respiration of $\mathrm{Fe}$ and $\mathrm{Mn}$.

\section{Redox cycling in chemically stratified environments}

The Black Sea is a prime example of a chemically (redox) stratified environment that exists over distances of tens of meters in the water column and where Fe and Mn undergo biogeochemical redox cycling (Nealson and Myers 1992). Fe and Mn are chemically unique ions in redox gradient environments because of their relatively low solubility in the oxidized state. As these metal ions are oxidized, either microbially or abiotically, they can precipitate and be subjected to gravitational settling into anoxic zones (Nealson and Saffarini 1994). As they enter the anoxic zones these precipitates can be reduced by DMRB coupled to organic matter oxidation at which point soluble species of $\mathrm{Fe}(\mathrm{II})$ and $\mathrm{Mn}$ (II) can diffuse upward into oxic zones. A number of excellent reviews have been published on this subject and the reader is directed to those for more information and examples (Burdige 1993; Nealson and Saffarini 1994; Nealson and Little 1997; Nealson et al. 2002). Previous investigations of redox stratified environments have justifiably focused on detailed geochemical characterization and baseline investigations into associated microbial properties using a combination of cultivation and cultivation-independent methods. The availability of whole genome sequences and the ability to sequence entire microbial communities (metagenomics) provide powerful tools to probe 
microbial processes in these environments in the future (for additional discussion see chapters by Whitaker and Banfield 2005 and Nelson and Methé 2005).

\section{Microscale redox cycling}

In addition to participating in redox cycling in chemocline environments that can span many meters, more recent research indicates that DMRB also participate in redox cycling over much shorter length scales. Because $\mathrm{Fe}(\mathrm{II})$ is rapidly oxidized by $\mathrm{O}_{2}$, neutrophilic microbial Fe oxidation is constrained to microaerobic environments where the abiotic oxidation of $\mathrm{Fe}(\mathrm{II})$ is limited by $\mathrm{O}_{2}$ availability and microbiologic rates of $\mathrm{Fe}(\mathrm{II})$ oxidation are competitive with abiotic rates. Hence, there is a potential for tight coupling between metal reduction and oxidation steps over short distance scales in environments with sharp microaerobic and anaerobic boundaries. In fact, it has been proposed that Fe(II)-oxidizing organisms localize themselves into a narrow band of cells and associated $\mathrm{Fe}(\mathrm{III})$ oxides to facilitate interfacing with DMRB (Roden et al. 2004). Such a coupling was experimentally investigated in microcosms consisting of ferrihydrite coated sand and a co-culture consisting of a lithotrophic Fe(II)-oxidizing bacterium (strain TW2) and the DMRB Shewanella alga strain BrY (Sobolev and Roden 2002). The co-culture exhibited minimal Fe oxide accumulation at the sand-water interface despite measurable dissolved $\mathrm{O}_{2}$ to a depth of $2 \mathrm{~mm}$ below the interface whereas a distinct layer of $\mathrm{Fe}$ oxide formed at this same interface in microcosms containing $\mathrm{BrY}$ alone. Direct microscopic observations revealed close juxtapositioning of both organisms in the upper few $\mathrm{mm}$ of sand. Subsequent investigations using the identical experimental system noted relatively low concentrations of $\mathrm{Fe}$ (II) in the co-culture relative to the microcosm containing $\mathrm{BrY}$ alone and suggested that $\mathrm{Fe}$ (III)-binding ligands impeded the formation of $\mathrm{Fe}(\mathrm{III})$ oxides and were responsible for a soluble/colloidal Fe(III) phase that facilitated the redox cycling of Fe (Roden et al. 2004). These results established the potential for a tight coupling between microbial metal reduction and oxidation processes to promote rapid microscale cycling of $\mathrm{Fe}$. More research, however, is needed to better define the nature and role of Fe(III)-complexing ligands in microscale Fe cycling and whether interactions between metal-reducing and metaloxidizing extend beyond simply Fe(II)-Fe(III) cycling.

\section{SUMMARY}

Most of the electron acceptors respired by prokaryotes $\left(\mathrm{O}_{2}, \mathrm{NO}_{3}{ }^{-}, \mathrm{SO}_{4}{ }^{2-}\right.$, and $\left.\mathrm{CO}_{2}\right)$ are soluble both before and after reduction, while many of the metals respired by DMRB exhibit substantially different solubility properties in the oxidized versus the reduced states. Because $\mathrm{Fe}(\mathrm{III})$ and $\mathrm{Mn}(\mathrm{III}, \mathrm{IV})$ exist predominantly as oxyhydroxide minerals in oxic environments, DMRB must overcome the fundamental problem of engagement of the electron transport system with poorly soluble minerals. Other metals, such as $\mathrm{U}(\mathrm{VI})$ and $\mathrm{Tc}(\mathrm{VII})$, are relatively soluble in oxic environments, typically as anionic uranyl carbonate complexes and as pertechnetate, respectively. Aqueous $\mathrm{Tc}(\mathrm{VII})$ and $\mathrm{U}(\mathrm{VI})$ and other soluble electron acceptors are therefore free to enter the cell periplasm through porins or channels in the OM. Upon reduction to the +4 oxidation state, however, $\mathrm{U}$ and Tc precipitate as uraninite and hydrous $\mathrm{Tc}(\mathrm{IV})$ oxides, phases that have been identified in anaerobic suspensions of DMRB cells incubated with $\mathrm{U}(\mathrm{VI})$ or $\mathrm{Tc}(\mathrm{VII})$ and appropriate electron donors. The dilemma of reducing soluble electron acceptors to insoluble end-products is no less serious than the one dealing with reduction of solid electron acceptors. The first section of this chapter has highlighted the latest findings on the novel respiratory strategies employed by DMRB to overcome this dilemma, including direct enzymatic reduction, electron shuttling pathways and metal solubilization by exogenous or bacterially-produced organic ligands followed by reduction of soluble organicmetal compounds. The second section has emphasized the geochemical consequences of DMRB activity, including the direct and indirect effects on metal solubility, the reductive 
transformation of Fe- and Mn-containing minerals, and the biogeochemical cycling of metals at redox interfaces in chemically stratified environments.

\section{ACKNOWLEDGMENTS}

The authors wish to thank David Bates, Justin Burns, Jason Dale, Amanda Payne and Tara Hoyem for help in manuscript preparation. The authors also with to thank Alice Donalkova, Dwayne Elias, David Kennedy, Matthew Marshall, and Andrew Plymale for providing the transmission electron microscopy images. Financial support for this work was provided by the National Science Foundation and the U.S. Department of Energy, Office of Biological and Environmental Research.

\section{REFERENCES}

Anderson RT, Lovley DR (1999) Naphthalene and benzene degradation under Fe(II)-reducing conditions in petroleum-contaminated aquifers. Biorem J 3:121-135

Arnold RG, DiChristina TJ, Hoffmann MR (1988) Reductive dissolution of iron-oxides by Pseudomonas sp. 200. Biotech Bioeng 32:1081-1096

Aubert C, Brugna M, Dolla A, Bruschi M, Giudici-Orticoni MT (2000) A sequential electron transfer from hydrogenases to cytochromes in sulfate-reducing bacteria. Biochim Biophys Acta 1476:85-92

Baedecker MJ, Cozzarelli IM, Eganhouse RP, Siegel DI, Bennett PC (1993) Crude-oil in a shallow sand and gravel aquifer. 3. Biogeochemical reactions and mass-balance modeling in anoxic groundwater. Appl Geochem 8:569-586

Bagramyan K, Trchounian A (2003) Structural and functional features of formate hydrogen lyase, an enzyme of mixed-acid fermentation from Escherichia coli. Biochemistry-Moscow 68:1159-1170

Beliaev AS, Saffarini DA (1998) Shewanella putrefaciens mtrB encodes an outer membrane protein required for $\mathrm{Fe}(\mathrm{III})$ and $\mathrm{Mn}(\mathrm{IV})$ reduction. J Bacteriol 180:6292-7

Bonneville S, Van Cappellen P, Behernds T (2004) Microbial reduction of iron(III) oxyhydroxides: effects of mineral solubility and availability. Chem Geol 212:255-268

Brooks SC, Fredrickson JK, Carroll SL, Kennedy DW, Zachara JM, Plymale AE, Kelly SD, Kemner KM, Fendorf S (2003) Inhibition of bacterial U(VI) reduction by calcium. Environ Sci Technol 37:1850-1858

Burdige DJ (1993) The biogeochemistry of manganese and iron reduction in marine-sediments. Earth-Science Reviews 35:249-284

Burdige DJ, Dhakar SP, Nealson KH (1992) Effects of manganese oxide mineralogy on microbial and chemical manganese reduction. Geomicrobiol J 10:27-48

Butler A (2003) Iron acquisition: straight up and on the rocks? Nature Struct Biol 10:240-241

Caccavo F, Blakemore RP, Lovley DR (1992) A hydrogen-oxidizing, Fe(III)-reducing microorganism from the Great Bay Estuary, New-Hampshire. Appl Environ Microbiol 58:3211-3216

Cervini-Silva J, Kostka JE, Larson RA, Stucki JW, Wu J (2003) Dehydrochlorination of 1,1,1-trichloroethane and pentachloroethane by microbially reduced ferruginous smectite. Environ Toxicol Chem 22:10461050

Chin KJ, Esteve-Nunez A, Leang C, Lovley DR (2004) Direct correlation between rates of anaerobic respiration and levels of mRNA for key respiratory genes in Geobacter sulfurreducens. Appl Environ Microbiol 70: 5183-5189

Coates JD, Cole KA, Chakraborty R, O'Connor SM, Achenbach LA (2002) Diversity and ubiquity of bacteria capable of utilizing humic substances as electron donors for anaerobic respiration. Appl Environ Microbiol 68:2445-52

Coates JD, Ellis DJ, Blunt-Harris EL, Gaw CV, Roden EE, Lovley DR (1998) Recovery of humic-reducing bacteria from a diversity of environments. Appl Environ Microbiol 64:1504-9

Cochran JK, Carey AE, Sholkovitz ER, Suprenant LD (1986) The geochemistry of uranium and thorium in coastal marine sediments and sediment pore waters. Geochim Cosmochim Acta 50:663-680

Cui DQ, Eriksen TE (1996) Reduction of pertechnetate by ferrous iron in solution: Influence of sorbed and precipitated Fe(II). Environ Sci Technol 30:2259-2262

Cummings DE, Caccavo F, Fendorf S, Rosenzweig RF (1999) Arsenic mobilization by the dissimilatory Fe(III)reducing bacterium Shewanella alga BrY. Environ Sci Technol 33:723-729

De Luca G, De Philip P, Dermoun Z, Rousset M, Vermeglio A (2001) Reduction of technetium(VII) by Desulfovibrio fructosovorans is mediated by the nickel-iron hydrogenase. Appl Environ Microbiol 67: 4583-4587 
Desvaux M, Parham NJ, Scott-Tucker A, Henderson IR (2004) The general secretory pathway: a general misnomer? Trends Microbiol 12:306-309

DiChristina TJ, Adiga M, Bates D, Burns J, Haller CA (2005) Submitted for review.

DiChristina TJ, DeLong EF (1994) Isolation of anaerobic respiratory mutants of Shewanella putrefaciens and genetic analysis of mutants deficient in anaerobic growth on $\mathrm{Fe}^{3+}$. J Bacteriol 176:1468-74

DiChristina TJ, Moore CM, Haller CA (2002) Dissimilatory Fe(III) and Mn(IV) reduction by Shewanella putrefaciens requires ferE, a homolog of the pulE (gspE) type II protein secretion gene. J Bacteriol 184: 142-51

Dong HL, Kostka JE, Kim J (2003a) Microscopic evidence for microbial dissolution of smectite. Clays Clay Mineral 51:502-512

Dong HL, Kukkadapu RK, Fredrickson JK, Zachara JM, Kennedy DW, Kostandarithes HM (2003b) Microbial reduction of structural Fe(III) in illite and goethite. Environ Sci Technol 37:1268-1276

Eriksen TE, Ndalamba P, Bruno J, Caceci M (1992) The solubility of $\mathrm{TcO}_{2} \bullet n \mathrm{H}_{2} \mathrm{O}$ in neutral to alkaline-solutions under constant $\mathrm{pCO}_{2}$. Radiochim Acta 58-9:67-70

Fendorf SE, Zasoski RJ (1992) Chromium(III) oxidation by delta- $\mathrm{MnO}_{2}$. Characterization. Environ Sci Technol 26:79-85

Filloux A (2004) The underlying mechanisms of type II protein secretion. Biochim Biophys Acta 1694:163179

Finch R, Murakami T (1999) Systematics and paragenesis of uranium minerals. Rev Mineral 38:91-180

Finneran KT, Anderson RT, Nevin KP, Lovley DR (2002) Potential for Bioremediation of uranium-contaminated aquifers with microbial U(VI) reduction. Soil Sediment Contam 11:339-357

Francis AJ, Dodge CJ, Lu FL, Halada GP, Clayton CR (1994) XPS and XANES studies of uranium reduction by Clostridium Sp. Environ Sci Technol 28:636-639

Fredrickson JK, Kota S, Kukkadapu RK, Liu CX, Zachara JM (2003) Influence of electron donor/acceptor concentrations on hydrous ferric oxide (HFO) bioreduction. Biodegradation 14:91-103

Fredrickson JK, Zachara JM, Kennedy DW, Dong HL, Onstott TC, Hinman NW, Li SM (1998) Biogenic iron mineralization accompanying the dissimilatory reduction of hydrous ferric oxide by a groundwater bacterium. Geochim Cosmochim Acta 62:3239-3257

Fredrickson JK, Zachara JM, Kennedy DW, Duff MC, Gorby YA, Li SMW, Krupka KM (2000) Reduction of $\mathrm{U}(\mathrm{VI})$ in goethite (alpha-FeOOH) suspensions by a dissimilatory metal-reducing bacterium. Geochim Cosmochim Acta 64:3085-3098

Fredrickson JK, Zachara JM, Kennedy DW, Kukkadapu RK, McKinley JP, Heald SM, Liu C, Plymale AE (2004) Reduction of $\mathrm{TcO}_{4}{ }^{-}$by sediment-associated biogenic Fe(II). Geochim Cosmochim Acta 68:3171-3187

Fredrickson JK, Zachara JM, Kennedy DW, Liu CX, Duff MC, Hunter DB, Dohnalkova A (2002) Influence of Mn oxides on the reduction of uranium(VI) by the metal-reducing bacterium Shewanella putrefaciens. Geochim Cosmochim Acta 66:3247-3262

Fredrickson JK, Zachara JM, Kukkadapu RK, Gorby YA, Smith SC, Brown CF (2001) Biotransformation of Nisubstituted hydrous ferric oxide by an Fe(III)-reducing bacterium. Environ Sci Technol 35:703-712

Ganesh R, Robinson KG, Reed GD, Sayler GS (1997) Reduction of hexavalent uranium from organic complexes by sulfate- and iron-reducing bacteria. Appl Environ Microbiol 63:4385-4391

Glasauer S, Weidler PG, Langley S, Beveridge TJ (2003) Controls on Fe reduction and mineral formation by a subsurface bacterium. Geochim Cosmochim Acta 67:1277-1288

Gilbert B, Banfield JF (2005) Molecular-scale processes involving nanoparticulate minerals in biogeochemical systems. Rev Mineral Geochem 59:109-155

Gorby YA, Lovley DR (1992) Enzymatic uranium precipitation. Environ Sci Technol 26:205-207

Grenthe I (1992) Chemical Thermodynamics of Uranium. North Holland, Amsterdam

Haas JR, DiChristina TJ (2002) Effects of Fe(III) chemical speciation on dissimilatory Fe(III) reduction by Shewanella putrefaciens. Environ Sci Technol 63:373-380

Haines RI, Owen DG, Vandergraaf TF (1987) Technetium-iron oxide reactions under anaerobic conditions: a Fourier transform infrared, FTIR study. Nuclear J Canada 1:32-37

Hansel CM, Benner SG, Neiss J, Dohnalkova A, Kukkadapu RK, Fendorf S (2003) Secondary mineralization pathways induced by dissimilatory iron reduction of ferrihydrite under advective flow. Geochim Cosmochim Acta 67:2977-2992

Hansel CM, Benner SG, Nico P, Fendorf S (2004) Structural constraints of ferric (hydr)oxides on dissimilatory iron reduction and the fate of Fe(II). Geochim Cosmochim Acta 68:3217-3229

Harada E, Kumagai J, Ozawa K, Imabayashi S, Tsapin AS, Nealson KH, Meyer TE, Cusanovich MA, Akutsu $\mathrm{H}$ (2002) A directional electron transfer regulator based on heme-chain architecture in the small tetraheme cytochrome $c$ from Shewanella oneidensis. FEBS Lett 532:333-7

Heidelberg JF, Paulsen IT, Nelson KE, Gaidos EJ, Nelson WC, Read TD, Eisen JA, Seshadri R, Ward N, Methé B, et al. (2002) Genome sequence of the dissimilatory metal ion-reducing bacterium Shewanella oneidensis. Nat Biotechnol 20:1118-23 
Hernandez ME, Kappler A, Newman DK (2004) Phenazines and other redox-active antibiotics promote microbial mineral reduction. Appl Environ Microbiol 70:921-8

Kukkadapu RK, Zachara JM, Fredrickson JK, Kennedy DW, Dohnalkova AC, McCready DE (2005) Ferrous hydroxy carbonate is a stable transformation product of biogenic magnetite. Am Mineral 90:510-515

Kashefi K, Lovley DR (2000) Reduction of Fe(III), Mn(IV), and toxic metals at 100 degrees C by Pyrobaculum islandicum. Appl Environ Microbiol 66:1050-1056

Khijniak TV, Medvedeva-Lyalikova NN, Simonoff M (2003) Reduction of pertechnetate by haloalkaliphilic strains of Halomonas. FEMS Microbiol Ecol 44:109-115

Kieft TL, Fredrickson JK, Onstott TC, Gorby YA, Kostandarithes HM, Bailey TJ, Kennedy DW, Li SW, Plymale AE, Spadoni CM, Gray MS (1999) Dissimilatory reduction of Fe(III) and other electron acceptors by a Thermus isolate. Appl Environ Microbiol 65:1214-1221

Kostka JE, Haefele E, Viehweger R, Stucki JW (1999) Respiration and dissolution of iron(III) containing clay minerals by bacteria. Environ Sci Technol 33:3127-3133

Kostka JE, Stucki JW, Nealson, KH, Wu J (1996) Reduction of structural Fe(III) in smectite by a pure culture of Shewanella putrefaciens MR-1. Clays Clay Mineral 44:522-529

Kostka JE, Luther GW, Nealson KH (1995) Chemical and biological reduction of Mn(III)-pyrophosphate complexes: potential importance of dissolved $\mathrm{Mn}(\mathrm{III})$ as an environmental oxidant. Geochim Cosmochim Acta 59:885-894

Kukkadapu RK, Zachara JM, Fredrickson JK, Kennedy DW (2004) Biotransformation of two-line silicaferrihydrite by a dissimilatory $\mathrm{Fe}(\mathrm{III})$-reducing bacterium: formation of carbonate green rust in the presence of phosphate. Geochim Cosmochim Acta 68:2799-2814

Kukkadapu RK, Zachara JM, Fredrickson JK, Smith SC, Dohnalkova AC, Russell CK (2003) Transformation of 2-line ferrihydrite to 6-line ferrihydrite under oxic and anoxic conditions. Am Mineral 88:1903-1914

Kukkadapu RK, Zachara JM, Smith SC, Fredrickson JK, Liu CX (2001) Dissimilatory bacterial reduction of Al-substituted goethite in subsurface sediments. Geochim Cosmochim Acta 65:2913-2924

Langmuir D (1997) Aqueous Environmental Geochemistry. Prentice Hall, Upper Saddle River, New Jersey

Leang C, Coppi MV, Lovley DR (2003) OmcB, a c-type polyheme cytochrome, involved in Fe(III) reduction in Geobacter sulfurreducens. J Bacteriol 185:2096-2103

Leang C, Lovley DR (2005) Regulation of two highly similar genes, OmcB and OmcC, in a $10 \mathrm{~kb}$ chromosomal duplication in Geobacter sulfurreducens. Microbiology-Sgm 151:1761-1767

Lengeler JW, Drews G, Schlegel HG (1999) Biology of the Prokaryotes. Georg Thieme Verlag, Stuttgart, Germany

Liger E, Charlet L, Van Cappellen P (1999) Surface catalysis of uranium(VI) reduction by iron(II). Geochim Cosmochim Acta 63:2939-2955

Liu CG, Zachara JM, Gorby YA, Szecsody JE, Brown CF (2001a) Microbial reduction of Fe(III) and sorption/ precipitation of $\mathrm{Fe}(\mathrm{II})$ on Shewanella putrefaciens strain CN32. Environ Sci Technol 35:1385-1393

Liu CX, Gorby YA, Zachara JM, Fredrickson JK, Brown CF (2002a) Reduction kinetics of Fe(III), Co(III), $\mathrm{U}(\mathrm{VI}) \mathrm{Cr}(\mathrm{VI})$ and $\mathrm{Tc}(\mathrm{VII})$ in cultures of dissimilatory metal-reducing bacteria. Biotechnol Bioeng 80: 637-649

Liu CX, Kota S, Zachara JM, Fredrickson JK, Brinkman CK (2001b) Kinetic analysis of the bacterial reduction of goethite. Environ Sci Technol 35:2482-2490

Liu CX, Zachara JM, Fredrickson JK, Kennedy DW, Dohnalkova A (2002b) Modeling the inhibition of the bacterial reduction of $\mathrm{U}(\mathrm{VI})$ by beta- $\mathrm{MnO}_{2}(\mathrm{~S})(\mathrm{g})$. Environ Sci Technol 36:1452-1459

Lloyd JR (2003) Microbial reduction of metals and radionuclides. FEMS Microbiol Rev 27:411-425

Lloyd JR, Cole JA, Macaskie LE (1997) Reduction and removal of heptavalent technetium from solution by Escherichia coli. J Bacteriol 179:2014-2021

Lloyd JR, Leang C, Myerson ALH, Coppi MV, Cuifo S, Methé B, Sandler SJ, Lovley DR (2003) Biochemical and genetic characterization of PpcA, a periplasmic c-type cytochrome in Geobacter sulfurreducens. Biochem J 369:153-161

Lloyd JR, Sole VA, Van Praagh CVG, Lovley DR (2000) Direct and Fe(II)-mediated reduction of technetium by Fe(III)-reducing bacteria. Appl Environ Microbiol 66:3743-3749

Lovley DR (1995) Bioremediation of organic and metal contaminants with dissimilatory metal reduction. J Indust Microbiol 14:85-93

Lovley DR, Coates JD, BluntHarris EL, Phillips EJP, Woodward JC (1996) Humic substances as electron acceptors for microbial respiration. Nature 382:445-448

Lovley DR, Holmes DE, Nevin KP (2004) Dissimilatory Fe(III) and Mn(IV) reduction. Adv Microb Physiol 49:219-86

Lovley DR, Phillips EJP (1986) Availability of ferric iron for microbial reduction in bottom sediments of the fresh-water Tidal Potomac River. Appl Environ Microbiol 52:751-757

Lovley DR, Phillips EJP (1988) Novel mode of microbial energy-metabolism - organic-carbon oxidation coupled to dissimilatory reduction of iron or manganese. Appl Environ Microbiol 54:1472-1480 
Lovley DR, Phillips EJP, Gorby YA, Landa ER (1991) Microbial reduction of uranium. Nature 350:413-416

Lovley DR, Stolz JF, Nord GL, Phillips EJP (1987) Anaerobic production of magnetite by a dissimilatory ironreducing microorganism. Nature 330:252-254

Lovley DR, Widman PK, Woodward JC, Phillips EJP (1993) Reduction of uranium by cytochrome-C(3) of Desulfovibrio Vulgaris. Appl Environ Microbiol 59:3572-3576

Lovley DR, Woodward JC (1996) Mechanisms for chelator stimulation of microbial Fe(III)-oxide reduction. Chem Geol 132:19-24

Lyalikova NN, Khizhnyak TV (1996) Reduction of heptavalent technetium by acidophilic bacteria of the genus Thiobacillus. Microbiology 65:468-473

Madigan MT, Martinko JM (2006) Brock Biology of Microorganisms Prentice Hall, Upper Saddle River, NJ

Methé BA, Webster J, Nevin K, Butler J, Lovley DR (2005) DNA microarray analysis of nitrogen fixation and Fe(III) reduction in Geobacter sulfurreducens. Appl Environ Microbiol 71:2530-2538

Meyer RE, Arnold WD, Case FI, O' Kelley GD (1991) Solubilities of Tc(IV)-oxides. Radiochim Acta 55:11-18

Myers CR, Myers JM (1992) Localization of cytochromes to the outer membrane of anaerobically grown Shewanella putrefaciens MR-1. J Bacteriol 174:3429-38

Myers CR, Myers JM (1993a) Ferric reductase is associated with the membranes of anaerobically grown Shewanella Putrefaciens MR-1. FEMS Microbiol Lett 108:15-22

Myers CR, Myers JM (1993b) Role of menaquinone in the reduction of fumarate, nitrate, iron(III) and manganese(IV) by Shewanella Putrefaciens MR-1. FEMS Microbiol Lett 114:215-222

Myers CR, Myers JM (1997) Cloning and sequence of cymA a gene encoding a tetraheme cytochrome c required for reduction of iron(III), fumarate, and nitrate by Shewanella putrefaciens MR-1. J Bacteriol 179:1143-1152

Myers CR, Myers JM (2002) MtrB is required for proper incorporation of the cytochromes OmcA and OmcB into the outer membrane of Shewanella putrefaciens MR-1. Appl Environ Microbiol 68:5585-94

Myers CR, Myers JM (2003a) Cell surface exposure of the outer membrane cytochromes of Shewanella oneidensis MR-1. Lett Appl Microbiol 37:254-258

Myers CR, Nealson KH (1988) Microbial reduction of manganese oxides - interactions with iron and sulfur. Geochim Cosmochim Acta 52:2727-2732

Myers CR, Nealson KH (1990) Respiration-linked proton translocation coupled to anaerobic reduction of manganese(IV) and iron(III) in Shewanella putrefaciens MR-1. J Bacteriol 172:6232-8

Myers JM, Myers CR (2000) Role of the tetraheme cytochrome CymA in anaerobic electron transport in cells of Shewanella putrefaciens MR-1 with normal levels of menaquinone. J Bacteriol 182:67-75

Myers JM, Myers CR (2001) Role for outer membrane cytochromes OmcA and OmcB of Shewanella putrefaciens MR-1 in reduction of manganese dioxide. Appl Environ Microbiol 67:260-9

Myers JM, Myers CR (2003b) Overlapping role of the outer membrane cytochromes of Shewanella oneidensis MR-1 in the reduction of manganese(IV) oxide. Lett Appl Microbiol 37:21-5

Nealson KH, Belz A, McKee B (2002) Breathing metals as a way of life: geobiology in action. Antonie Van Leeuwenhoek Int J Gen Molec Microbiol 81:215-222

Nealson KH, Little B (1997) Breathing manganese and iron: solid-state respiration. Adv Appl Microbiol 45: 213-239

Nealson KH, Myers CR (1992) Microbial reduction of manganese and iron: new approaches to carbon cycling. Appl Environ Microbiol 58:439-43

Nealson KH, Saffarini D (1994) Iron and manganese in anaerobic respiration - environmental significance, physiology, and regulation. Annu Rev Microbiol 48:311-343

Nelson KE, Methé B (2005) Metabolism and genomics: adventures derived from complete genome sequencing. Rev Mineral Geochem 59:279-294

Nevin KP, Lovley DR (2000) Lack of production of electron-shuttling compounds or solubilization of Fe(III) during reduction of insoluble Fe(III) oxide by Geobacter metallireducens. Appl Environ Microbiol 66: $2248-2251$

Nevin KP, Lovley DR (2002) Mechanisms for accessing insoluble Fe(III) oxide during dissimilatory Fe(III) reduction by Geothrix fermentans. Appl Environ Microbiol 68:2294-2299

Newman DK, Gralnick JA (2005) What genetics offers geobiology. Rev Mineral Geochem 59:9-26

Newman DK, Kolter R (2000) A role for excreted quinones in extracellular electron transfer. Nature 405:94-97

Ortiz-Bernad I, Anderson RT, Vrionis HA, Lovley DR (2004) Resistance of solid-phase U(VI) to microbial reduction during in situ bioremediation of uranium-contaminated groundwater. Appl Environ Microbiol 70:7558-7560

Pasilis SP, Pemberton JE (2003) Speciation and coordination chemistry of uranyl(VI)-citrate complexes in aqueous solution. Abstr Papers Am Chem Soc 225:U807-U807

Payne AN, DiChristina TJ (2005) Submitted for review.

Payne RB, Gentry DM, Rapp-Giles BJ, Casalot L, Wall JD (2002) Uranium reduction by Desulfovibrio desulfuricans strain G20 and a cytochrome $c_{3}$ mutant. Appl Environ Microbiol 68:3129-3132 
Payne RB, Casalot L, Rivere T, Terry JH, Larsen L, Giles BJ, Wall JD (2004) Interaction between uranium and the cytochrome $c_{3}$ of Desulfovibrio desulfuricans strain G20. Arch Microbiol 181:398-406

Pitts KE, Dobbin PS, Reyes-Ramirez F, Thomson AJ, Richardson DJ, Seward HE (2003) Characterization of the Shewanella oneidensis MR-1 decaheme cytochrome MtrA: expression in Escherichia coli confers the ability to reduce soluble Fe(III) chelates. J Biol Chem 278:27758-65

Pugsley AP (1993) The complete general secretory pathway in gram-negative bacteria. Microbiol Rev 57:50108

Pugsley AP, Francetic O, Hardie K, Possot OM, Sauvonnet N, Seydel A (1997) Pullulanase: model protein substrate for the general secretory pathway of gram-negative bacteria. Folia Microbiologica 42:184-192

Rai D, Felmy AR, Ryan JL (1990) Uranium(IV) hydrolysis constants and solubility product of $\mathrm{UO}_{2} \cdot \mathrm{xH}_{2} \mathrm{O}(\mathrm{Am})$. Inorganic Chemistry 29:260-264

Rard JA (1999) Chemical Thermodynamics of Technetium. Elsevier, Amsterdam.

Rard JA (1983) Critical review of the chemistry and thermodynamics of technetium and some of its inorganic compounds and aqueous species. Livermore, California

Richardson DJ (2000) Bacterial respiration: a flexible process for a changing environment. Microbiology-Sgm 146:551-571

Roden EE (2003) Fe(III) oxide reactivity toward biological versus chemical reduction. Environ Sci Technol 37: 1319-1324

Roden EE, Sobolev D, Glazer B, Luther GW (2004) Potential for microscale bacterial Fe redox cycling at the aerobic-anaerobic interface. Geomicrobiol J 21:379-391

Roden EE, Urrutia MM (1999) Ferrous iron removal promotes microbial reduction of crystalline iron(III) oxides. Environ Sci Technol 33:2492-2492

Roden EE, Urrutia MM (2002) Influence of biogenic Fe(II) on bacterial crystalline Fe(III) oxide reduction. Geomicrobiol J 19:209-252

Roden EE, Urrutia MM, Mann CJ (2000) Bacterial reductive dissolution of crystalline Fe(III) oxide in continuous-flow column reactors. Appl Environ Microbiol 66:1062-1065

Roden EE, Zachara JM (1996) Microbial reduction of crystalline iron(III) oxides: influence of oxide surface area and potential for cell growth. Environ Sci Technol 30:1618-1628

Rooney-Varga JN, Anderson RT, Fraga JL, Ringelberg D, Lovley DR (1999) Microbial communities associated with anaerobic benzene degradation in a petroleum-contaminated aquifer. Appl Environ Microbiol 65: 3056-3063

Saffarini DA, Blumerman SL, Mansoorabadi KJ (2002) Role of menaquinones in Fe(III) reduction by membrane fractions of Shewanella putrefaciens. J Bacteriol 184:846-8

Saltikov CW, Cifuentes A, Venkateswaran K, Newman DK (2003) The ars detoxification system is advantageous but not required for As(V) respiration by the genetically tractable Shewanella species strain ANA-3. Appl Environ Microbiol 69:2800-2809

Schwalb C, Chapman SK, Reid GA (2003) The tetraheme cytochrome CymA is required for anaerobic respiration with dimethyl sulfoxide and nitrite in Shewanella oneidensis. Biochemistry 42:9491-9497

Shyu JB, Lies DP, Newman DK (2002) Protective role of tolC in efflux of the electron shuttle anthraquinone2,6-disulfonate. J Bacteriol 184:1806-10

Sobolev D, Roden EE (2002) Evidence for rapid microscale bacterial redox cycling of iron in circumneutral environments. Antonie Van Leeuwenhoek Int J Gen Molec Microbiol 81:587-597

Stumm W (1992) Chemistry of the Solid-Water Interface. Wiley Interscience, New York.

Suzuki Y, Kelly SD, Kemner KM, Banfield JF (2002) Radionuclide contamination - nanometer-size products of uranium bioreduction. Nature 419:134-134

Taillefert M, DiChristina TJ (2005) Submitted for review.

Taillefert M, Hover VC, Rozan TF, Theberge SM, Luther III GW (2002) The influence of sulfides on soluble organic-Fe(III) in anoxic sediment porewaters. Estuaries 25:1088-1096

Turick CE, Tisa LS, Caccavo F Jr. (2002) Melanin production and use as a soluble electron shuttle for Fe(III) oxide reduction and as a terminal electron acceptor by Shewanella algae BrY. Appl Environ Microbiol 68: 2436-44

Urrutia MM, Roden EE, Zachara JM (1999) Influence of aqueous and solid-phase Fe(II) complexants on microbial reduction of crystalline iron(III) oxides. Environ Sci Technol 33:4022-4028

Wade R, DiChristina TJ (2000) Isolation of U(VI) reduction-deficient mutants of Shewanella putrefaciens. FEMS Microbiol Lett 184:143-148

Whitaker RJ, Banfield JF (2005) Population dynamics through the lens of extreme environments. Rev Mineral Geochem 59:259-277

Wielinga B, Bostick B, Hansel CM, Rosenzweig RF, Fendorf S (2000) Inhibition of bacterially promoted uranium reduction: Ferric (hydr)oxides as competitive electron acceptors. Environ Sci Technol 34:21902195 
Wielinga B, Mizuba MM, Hansel CM, Fendorf S (2001) Iron promoted reduction of chromate by dissimilatory iron-reducing bacteria. Environ Sci Technol 35:522-527

Wildung RE, Gorby YA, Krupka KM, Hess NJ, Li SW, Plymale AE, McKinley JP, Fredrickson JK (2000) Effect of electron donor and solution chemistry on products of dissimilatory reduction of technetium by Shewanella putrefaciens. Appl Environ Microbiol 66:2451-2460

Wildung RE, Li SW, Murray CJ, Krupka KM, Xie Y, Hess NJ, Roden EE (2004) Technetium reduction in sediments of a shallow aquifer exhibiting dissimilatory iron reduction potential. FEMS Microbiol Ecol 49:151-162

Zachara JM, Fredrickson JK, Li SM, Kennedy DW, Smith SC, Gassman PL (1998) Bacterial reduction of crystalline $\mathrm{Fe}^{3+}$ oxides in single phase suspensions and subsurface materials. Am Mineral 83:1426-1443

Zachara JM, Fredrickson JK, Smith SC, Gassman PL (2001) Solubilization of Fe(III) oxide-bound trace metals by a dissimilatory $\mathrm{Fe}(\mathrm{III})$ reducing bacterium. Geochim Cosmochim Acta 65:75-93

Zachara JM, Kukkadapu RK, Gassman PL, Dohnalkova A, Fredrickson JK, Anderson T (2004) Biogeochemical transformation of Fe minerals in a petroleum-contaminated aquifer. Geochim Cosmochim Acta 68:17911805

Zachara JM, Kukkadapu RK, Fredrickson JK, Gorby YA, Smith SC (2002) Biomineralization of poorly crystalline $\mathrm{Fe}(\mathrm{III})$ oxides by dissimilatory metal reducing bacteria. Geomicrobiol J 19:179-207 